\title{
Revision of some fossil podotrematous Brachyura (Homolodromiidae; Longodromitidae; Torynommidae)
}

\author{
Carrie E. Schweitzer and Rodney M. Feldmann
}

With 10 figures and 4 tables

Schweitzer, C.E. \& Feldmann, R.M. (2011): Revision of some fossil podotrematous Brachyura (Homolodromiidae; Longodromitidae; Torynommidae). - N. Jb. Geol. Paläont. Abh., DOI: 10.1127/00777749/2011/0138; Stuttgart.

\begin{abstract}
Podotrematous crabs from the Cretaceous worldwide are examined and reassigned, resulting in Vespridromites new genus, Notiodromia new genus, and Antarctiprosopon new genus, and seven new combinations. Torynommidae is severely restricted. Longodromitidae as currently recognized extends into the Eocene and has a well-established Cretaceous record.
\end{abstract}

Key words: Cretaceous, Decapoda, Eocene, Dromiacea, Homolodromioidea.

\section{Introduction}

Torynommidae was originally erected by GLAESSNER (1980) for Cretaceous brachyurans that were not well accommodated by existing families. Equivocation over placement of genera within the family reflects the tenuous nature of the relationships among and between the genera. Examination of type material, either specimens or photographs, suggests that the family is polyphyletic and that at least one genus within the family as previously construed, Dioratiopus Woods, 1953, is composed of several genera. We restrict Torynommidae Glaessner, 1980, to the type and possibly one other genus. The remainder of the genera historically placed within Torynommidae are removed to other families, principally Longodromitidae SCHWEITZER \& Feldmann, 2009a.

The availability of new material referable to Longodromitidae makes it possible to add significantly to our knowledge of that family and precipitated reexamination of other taxa referred to Podotremata. As a result, several taxa were identified that are clearly referable to Longodromitidae based upon dorsal carapace char- acters that also retain significant portions of the sternum and abdomen. Thus, for the first time we provide diagnostic features for Longodromitidae that include characters other than those of the dorsal carapace. We also found that morphological evidence strongly suggests that members of Longodromitidae range from the Middle Jurassic to the Eocene, a significant range extension and one not to be taken lightly. However, the very strong morphological similarities among the taxa herein referred to Longodromitidae (Fig. 1) indicate that there is no better placement for them at this time. Other taxa examined herein are placed within Homolodromiidae.

Institutional abbreviations: BMNH, The Natural History Museum, London, UK; KSU D, Decapod collection, Kent State University, Kent, Ohio; NMHW, Naturhistorisches Museum Wien [Vienna], Austria; ODG, Oertijdmuseum De Groenepoort, Boxtel, The Netherlands; QMF, UQF, F, Queensland Museum, Queensland, Australia; SDSM, SDSMT, South Dakota School of Mines and Technology, Rapid City, South Dakota; USNM, United States National Museum of Natural History, Smithsonian Institution, Washington, D. C. 


\section{Systematic paleontology}

\author{
Infraorder Brachyura LinNAEUs, 1758 \\ Section Dromiacea De HAAN, 1833 \\ Superfamily Glaessneropsoidea PATRULIUS, 1959
}

Discussion: Based upon the features of Longodromitidae discussed below, at least some Glaessneropsoidea are characterized by having a distinct pleural suture; a sometimes well-calcified pterygostome; all female abdominal somites free and becoming progressively longer and wider toward the telson and with three swellings, axial and lateral; a very long telson, twice as long as somite 6 and extending well beyond the coxae of pereiopod 1; pereiopod 5 subdorsal and small; and pereiopod 4 not particularly reduced in size. This combination of features does not diagnose any other family or superfamily within the Brachyura (Table 1). It will be necessary to recover material with preserved sterna and abdomina from other families within the Glaessneropsoidea to determine if this combination of characters indeed characterizes the entire superfamily.

\section{Family Longodromitidae SchweItzer \& Feldmann, $2009 \mathrm{a}$}

Included genera: Abyssophthalmus Schweitzer \& FeldMANN, 2009a; Antarctiprosopon new genus; Coelopus ÉTALLON, 1861; Dioratiopus Woods, 1953; Glaessnerella WrIGHT \& Collins, 1975; Longodromites Patrulius, 1959; Planoprosopon Schweitzer, Feldmann \& LazăR, 2007; Vespridromites new genus.

Diagnosis: Carapace longer than wide or about as wide as long, usually widest at position of epibranchial or anteriormost branchial region, dorso-ventrally compressed; rostrum projected well beyond orbits and augenrest, axially sulcate, markedly downturned distally; orbits under rostrum; augenrest shallow or deep, forward-directed, usually with intraand outer-augenrest spines as well as submarginal spines; protogastric and hepatic regions poorly differentiated; cervical groove deep, originating well posterior to outer-orbital spine; area between cervical and branchiocardiac grooves narrow; postcervical groove present, discontinuous and extending laterally about half the distance to the lateral margins or composed of two discrete segments that meet axially and extend laterally; cardiac region rounded triangular; epibranchial region with rounded or digitate projection directed toward cardiac region; subhepatic swelling positioned below orbit, bounded by ventral extension of cervical groove and antennar groove; ventral extensions of cervical and branchiocardiac grooves meeting to form subtriangular subdorsal extension of epibranchial region; pleural suture distinct, pterygostome sometimes well calcified; male and female abdominal somites free, becoming progressively longer and wider toward telson; each somite with three swellings, axial and lateral; telson very long, twice as long as somite 6 , extending well beyond coxae of pereiopod 1; pereiopod 5 subdorsal, small; pereiopod 4 ventral, not particularly reduced in size.
Discussion: Schweitzer \& Feldmann (2009a) erected the family for three genera embracing nine species and later added more genera and species to it (SchweITZer \& FelDMANN 2009b, 2010a). Herein we document the first reported longodromitid taxa with preserved sterna and abdomina, yielding a much more morphologically complete record for the family. The abdomen in both males and females, which is long, wide, and with a long telson, is typical of dromiaceans. Comparison of the observed features of the abdomen and the pereiopods with those of other members of Dromiacea shows that the combination of characteristics within Longodromitidae is unique, supporting its placement within its own family (Table 1). Recovery of more specimens with features of the sternum, abdomen, and pereiopods preserved, especially Jurassic forms, will help to confirm the diagnostic characteristics for this family and eventually for the superfamily.

Herein we refer to the depressed area lateral to the rostrum as the augenrest. We debated on the terminology and decided that although the structure is different from that in Goniodromitidae Beurlen, 1932, where the augenrest is clearly adjacent to the orbit and separated by a ridge, the structure in longodromitids is similar to the augenrest structures in Homolodromiidae Alcock, 1900, in which it is a depression surrounded by spines or other protective structures. In either case it is a separate structure from the orbit.

Referral of Dioratiopus and Vespridromites new genus to Longodromitidae constitute moderate geologic and geographic range extensions. Inclusion of Antarctiprosopon new genus is a major geologic and geographic range extension to the Longodromitidae. We recognize the inherent problems in this; however, comparison of the dorsal carapace features of these three taxa with those of confirmed longodromitids from the Jurassic (Fig. 1) strongly suggests that they are members of the same family. Further, we know, based upon the features of the abdomen and sternum, that Dioratiopus, Vespridromites, and Antarctiprosopon, are not referable to existing families within Dromiacea (Table 1), nor within Homoloidea De HAAN, 1839, or Cyclodorippoidea ORTMANN, 1892, other podotrematous brachyurans, for that matter. Members of Homoloidea have a telson that narrows strongly distally and interlocks with the bases of the third maxillipeds. In addition, the abdomen itself interlocks with the bases of the first through third pereiopods. We see no evidence of this type of telson or interlocking mechanism in any of the genera herein referred to Longodromitidae. Further, the anterior sternites 1-5 in homoloids are flattened and sternites 1-3 are short. In Antarctiprosopon, the sternum is very narrow and sternites $1-3$ are long and slender, typical of Dromiacea. Thus we feel confident in our placement of these genera within Longodromitidae. Recovery of Jurassic longodromitids with preserved sterna and/or abdomina would certainly confirm the placement.

\section{Genus Dioratiopus Woods, 1953}

Type and sole species: Dioratiopus salebrosus Woods, 1953, by original designation.

Diagnosis: Carapace rectangular, maintaining width from outer-orbital angle to posterior corner; rostrum narrow, pro- 


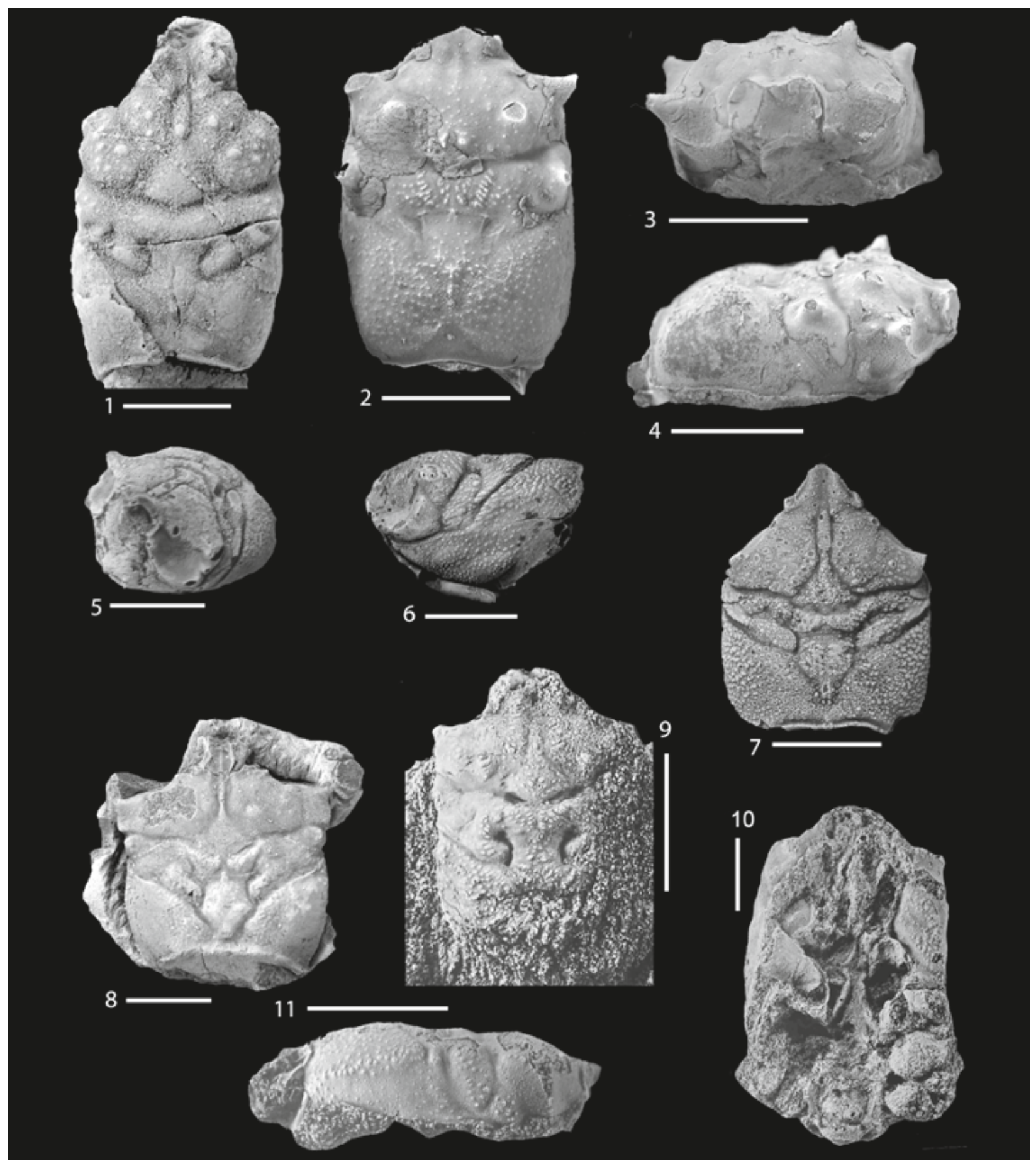

Fig. 1. Longodromitidae. 1 - Planoprosopon heydeni (von MeYer, 1857), neotype, Museum Tübingen, QuEnSTEDT, Jura, 1857, pl. 95, fig. 36, Oerlingen near Ulm, Germany, Upper Jurassic; 2-4 - P. schweigerti SchweITZER \& FELDMANN, 2009b, holotype, NHMW 1990/0041/3477, Ernstbrunn Limestone, Tithonian, dorsal carapace (2), anterior view (3), and lateral view (4); 5, 7 - Glaessnerella spinosa (VAN Straelen, 1936), cast of (BMNH) In. 60991 numbered KSU D 831, Kent, UK, Albian, oblique anterior view (5) and dorsal carapace (7); 6 - Glaessnerella spinosa (VAN STRAELEN, 1936), cast of J. S. H. Collins Collection \# 2425e numbered KSU D 1230, Kent, UK, Albian, lateral view showing pleural suture and calcified pterygostome ventral to it; 8 - Vespridromites hearttailensis (Bishop, 1985), SDSMT I3999, Belle Fourche, South Dakota, USA, Pierre Shale, Campanian; 9-11 - Antarctiprosopon chaneyi (Feldmann \& Wilson, 1988), Seymour Island, Antarctica, La Meseta Formation, Eocene, dorsal carapace, USNM 404872, paratype (9), ventral surface including sternum, USNM 404870, holotype (10), lateral view, USNM 404871, paratype (11). Scale bars $=1 \mathrm{~cm}$. 
Table 1. Comparison of key abdominal and pereiopod features of Homolodromioidea Alcock, 1900, and Dromioidea De HaAn, 1839, as defined by Schweitzer \& Feldmann (2010b), and Torynommidae.

\begin{tabular}{|c|c|c|c|c|c|c|}
\hline & $\begin{array}{l}\text { Homolodromi- } \\
\text { idae }\end{array}$ & Dromiidae & Dynomenidae & $\begin{array}{l}\text { Sphaerodromi- } \\
\text { idae }\end{array}$ & $\begin{array}{l}\text { Vespridromites } \\
\text { new genus } \\
\text { (Longodromiti- } \\
\text { dae) }\end{array}$ & $\begin{array}{l}\text { Torynomma } \\
\text { (Torynommidae) }\end{array}$ \\
\hline Oldest & $\begin{array}{l}\text { Lower Jurassic } \\
\text { (Pliensbachian) } \\
\text { (for superfamily) }\end{array}$ & Eocene & Late Cretaceous & $\begin{array}{l}\text { Late Cretaceous } \\
\text { (Campanian) }\end{array}$ & $\begin{array}{l}\text { Late Cretaceous } \\
\text { (Campanian) }\end{array}$ & $\begin{array}{l}\text { Early Cretaceous } \\
\text { (Albian) }\end{array}$ \\
\hline Uropod visible & No & Sometimes & Yes & Yes & No & No \\
\hline $\begin{array}{l}\text { Male telson longer } \\
\text { than wide }\end{array}$ & Yes & Rarely & No & Yes & Yes & $\begin{array}{l}\text { Yes in females } \\
\text { (males unk- } \\
\text { nown) }\end{array}$ \\
\hline $\begin{array}{l}\text { Abdominal somite } \\
6 \text { with triangular } \\
\text { epimeres }\end{array}$ & Yes & No & Yes & Yes & No & Yes \\
\hline $\begin{array}{l}\text { Abdominal somites } \\
1-5 \text { with long epi- } \\
\text { meres }\end{array}$ & Yes & No & No & No & No & Yes \\
\hline $\begin{array}{l}\text { Both P4 and P5 } \\
\text { reduced in size }\end{array}$ & Yes & Yes & No & Yes & No & Yes \\
\hline
\end{tabular}

jecting well-beyond orbits and augenrest; augenrest broad, with intra-augenrest spine and probably anterolaterally directed outer-augenrest spine, fronto-orbital width including augenrest about 95 percent maximum carapace width; lateral margins straight, parallel; constricted where intersected by cervical, post-cervical, and branchiocardiac grooves; cardiac region long, obovate, tapering distally, terminating well before posterior margin; intestinal region moderately long, poorly defined. Cervical groove broadly V-shaped; postcervical groove composed of a continuous segment across axis and then discontinuous short segments that intersect lateral margin; branchiocardiac groove parallel to cervical groove.

Flank vertical; cervical groove extending onto flank in convex forward arc, then arcing around small, weakly inflated subhepatic region; branchiocardiac groove extending onto flank in obliquely anteriorly directed path, intersecting cervical groove just posterior to subhepatic region; postcervical groove extending onto flank for short distance in convex forward arc; pleural suture clear, pterygostome well calcified, pleural suture inscribing path similar to that seen in Homolodromiidae.

Discussion: Dioratiopus has historically been referred to Torynommidae (GlaESSNER 1969; Schweitzer et al. 2010). However, examination of photographs of the type material and specimens of the type species of Torynomma and Dioratiopus suggests that the two genera are not referable to the same family. Torynomma bears a narrow front and very broad orbits, different than those of Dioratiopus. The orbits and the frontal margin of the carapace of Torynomma are nearly straight, whereas those of Dioratiopus angle posteriorly so that the outer-orbital angle is set well-posterior to the rostral base. In Torynomma, the cervical groove has an hepatic groove extending anteriorly from it that intersects the lateral margin; Dioratiopus lacks this groove. In Dioratiopus, the postcervical groove extends onto the flank from the lateral margin, whereas in Torynomma, lateral extensions of the postcervical are absent.

Dioratiopus is placed within Longodromitidae based upon its possession of deep orbits and orbital ornamentation, a narrow rostrum, a well-defined cervical groove originating posterior to the orbits on the lateral margin, parallel lateral margins, well-developed cervical, branchiocardiac, and postcervical grooves; a digitate projection on the epibranchial region, short flanks, and a triangular subdorsal extension of the epibranchial region. It differs from other genera within Longodromitidae in possessing a postcervical groove that extends onto the flanks and in being about as long as wide. It is similar to Planoprosopon, with which it shares an intraorbital spine near the base of the rostrum, an anterolaterally directed outer-orbital spine, and ornamented epibranchial region. However, Dioratiopus possesses a postcervical groove that extends laterally and onto the flank, which is absent in Planoprosopon. Some species of Abyssophthalmus also have some evidence of a slight postcervical groove laterally (Schweitzer \& Feldmann 2009b, fig. 3 ), but it is not nearly as well-developed as in Dioratiopus.

Species of Dioratiopus sensu stricto possess a wellcalcified pterygostomial region ventral to the pleural suture (= linea dromica). The holotype of D. salebrosus illustrates this feature (Fig. 2.2). In addition, the pleural suture is wellobserved on Glaessnerella spinosus (KSU D 9050), and the pterygostome is preserved and apparently well-calcified. No other members of Longodromitidae possess a preserved pterygostomial region, except possibly Vespridromites spp., so it is unknown if it was well-calcified in other members of the family. The presence of a well-calcified pterygostome 


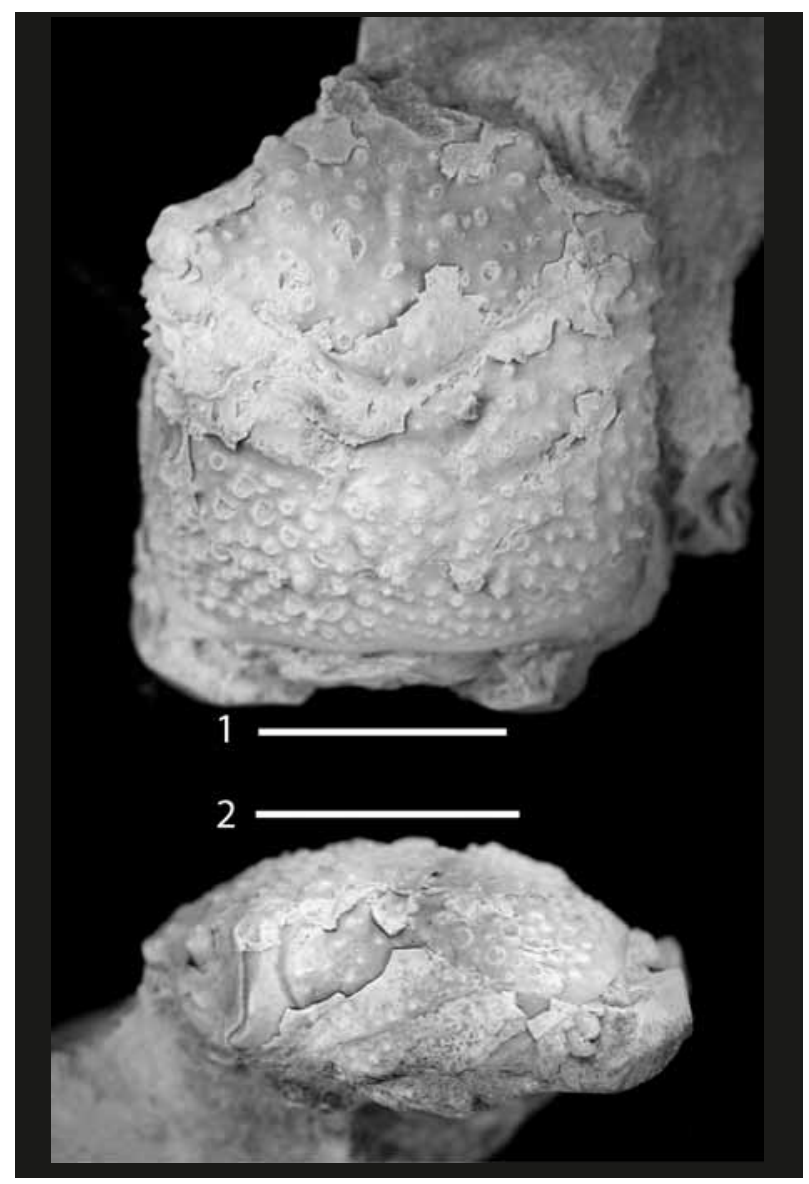

Fig. 2. Dioratiopus salebrosus Woods, 1953, holotype, F14927, Queensland, Australia, Albian, 1 - dorsal carapace; 2 - lateral view showing flanks and oblique view of orbit; note pleural suture and calcified pterygostome ventral to it. Scale bars $=1 \mathrm{~cm}$.

is quite distinctive, and its presence in two genera suggests it may have been a characteristic of the family. None of the mainly Jurassic genera retains any of the features ventral to the dorsal carapace.

GLAESSNER (1980) synonymized Glaessnerella with Dioratiopus, with which we do not concur. We herein resurrect Glaessnerella to accommodate several European species. Glaessnerella and Dioratiopus differ in several important respects, and we regard the similarities discussed by GLAESSNER (1980) to be features of the family. Glaessnerella has deep orbits that are obliquely directed, whereas Dioratiopus has shallower, forward directed orbits. The cervical groove in Dioratiopus extends in a convex forward arc onto the flank, whereas in Glaessnerella, it extends onto the flank in a concave forward arc. These are major features of the carapace and strongly indicate that the taxa should be separated.

Several species originally or subsequently referred to Dioratiopus are not referable to that genus. Bishop (1985) named the species Dioratiopus hearttailensis, which is herein placed within Vespridromites new genus. Dioratiopus dawsonensis (BISHOP, 1985) and Dioratiopus scotti Bishop, 1983, are also referred to that new genus. Diora- tiopus primitivus FraAYe \& Collins, 1996, is most likely a member of Coelopus, based upon its quadrate carapace, narrow metagastric region; very short anterolateral and very long posterolateral margins; lack of a postcervical groove laterally; and a cardiac region set well-anterior to the posterior margin. Coelopus primitivus new combination is latest Tithonian - earliest Berriasian in age from the south coast of the United Kingdom, making it the youngest member of Coelopus. Coelopus was already known from France ( $\mathrm{SCH}-$ WeITZER \& FELdMANn 2010a), so the geographic extension to the southern UK is not surprising. Thus, Dioratiopus as currently construed contains a single species, known from the late Albian of central Queensland, Australia (Woods 1953).

Dioratiopus salebrosus Woods, 1953

Fig. 2

1953 Dioratiopus salebrosus Woods, p. 53, fig. 2, pl., 2, figs. 4-5.

1969 Doratiopus [sic] Woods. - Glaessner, p. R493, fig. 304.2a-c.

1980 Dioratiopus salebrosus Woods. - Glaessner, p. 183, fig. 12.

2010 Dioratiopus salebrosus Woods. - SchweITZER et al., p. 80 .

Material examined: Photographs of uqf14927, holotype.

Occurrence: Albian, central Queensland, Australia (Woods 1953).

Diagnosis: As for genus.

Description: Carapace rectangular, slightly longer than wide, W/L about 0.90 , maintaining width from outer-augenrest angle to posterior corner; moderately vaulted longitudinally; regions with moderate-size granules overall, somewhat more densely spaced posteriorly. Rostrum narrow, about one-third carapace width, projecting well-beyond orbits and augenrests. Orbits placed under rostrum; augenrest broad, with intra-marginal spine and probably anterolaterally directed outer-augenrest spine, fronto-orbital width including augenrest about 95 percent maximum carapace width. Lateral margins straight, parallel to one another, constricted where intersected by cervical, post-cervical, and branchiocardiac grooves; short spines between cervical and branchiocardiac incisions and possibly posterior to branchiocardiac incision. Posterior margin rimmed, sinuous. Mesogastric region with long, narrow anterior process, widened distally into triangular region. Protogastric region broad, weakly inflated; hepatic region small, short, depressed below level of protogastric region. Metagastric region wide, narrowing posteriorly; urogastric region depressed, narrow; cardiac region long, obovate, tapering distally; intestinal region moderately long, poorly defined. Epibranchial region composed of weak ridges defined by segments of postcervical groove, with high digitate projection directed at cardiac region. Remainder of branchial region undifferentiated.

Cervical groove broadly V-shaped. Postcervical groove composed of a continuous segment across axis and then discontinuous short segments that intersect lateral margin. Branchiocardiac groove parallel to cervical groove. 
Table 2. Measurements (in mm) taken on the dorsal carapace of casts of specimens of Glaessnerella spinosa.

\begin{tabular}{llll}
\hline Specimen Number & Carapace Length & Carapace Width & Fronto-orbital Width \\
\hline KSU D 9050 & 18.2 & 15.9 & 14.5 \\
KSU D 4945 & 16.0 & 14.5 & 12.2 \\
KSU D 4948 & $\sim 12.5$ & 12.7 & - \\
KSU D 831 & 12.4 & 10.8 & 9.9 \\
\hline
\end{tabular}

Flank vertical. Cervical groove extending onto flank in convex forward arc, then arcing around subhepatic region. Subhepatic region small, weakly inflated. Branchiocardiac groove extending onto flank in obliquely anteriorly directed path, intersecting cervical groove just posterior to subhepatic region. Postcervical groove extending onto flank for short distance in convex forward arc. Pleural suture clear, pterygostome well calcified, pleural suture inscribing path similar to that seen in Homolodromiidae.

\section{Genus Glaessnerella Wright \& ColLins, 1975}

1972 Glaessneria Wright \& Collins, p. 34.

1975 Glaessnerella Wright \& Collins, p. 441.

Type species: Homolopsis spinosa VAn Straelen, 1936, by original designation.

Included species: Glaessnerella angusta (WRIGHT \& COLLINS, 1972); G. balli (WRIGHT \& Collins, 1972); G. decipiens (Wright \& Collins, 1972); G. depressa (CARTER, 1898), as Homolopsis; G. kennedyi (Wright \& Collins, 1972); G. latteri (Wright \& Collins, 1972); G. spinosa (VAN Straelen, 1936).

Material examined: Glaessnerella angusta, holotype (BMNH) In. 60924; Glaessnerella balli, holotype (BMNH) In. 60925 and paratype (BMNH) In. 60926; Glaessnerella decipiens, holotype (BMNH) B 41129; Glaessnerella depressa, lectotype (BMNH) B 30743; Glaessnerella kennedyi, holotype (BMNH) In. 61135; Glaessnerella latteri, holotype (BMNH) In. 60923; Glaessnerella spinosa, (BMNH) In. 60991 and casts numbered KSU D 831; KSU D 1230, cast of JSHC 2425e, in the private collection of J. S. H. Collins, London, UK.

Nomenclature: WRIGHT \& CoLLINS (1972) originally erected Glaessneria for several species from northern Europe. In 1975 , they renamed the genus Glaessnerella as Glaessneria was preoccupied.

Diagnosis: Carapace longer than wide, widening slightly posteriorly, widest in mid-branchial regions; flanks steep, perpendicular to dorsal surface. Rostrum long, directed anteriorly and dorsally, with tip downturned perpendicular to remainder of rostral surface; augenrest large, oblique, with inner and outer supramarginal spines, small lower inner augenrest spine. Lateral margins overall straight; cervical groove incising margin a short distance from outer-augen- rest spine; weak incision from discontinuous postcervical groove midway between cervical and weak branchiocardiac incision; margin posterior to branchiocardiac incision very long, rounding into posterior margin. Cardiac region triangular, apex directed posteriorly. Intestinal region poorly defined. Postcervical groove discontinuous, composed of deep segment across axis and weak arcuate convex forward segments on lateral margins connected to axial segment by discontinuous arc-like pits. Epibranchial region overall linear, directed at axial regions, with distinctive arcuate regions defined by postcervical groove. Subhepatic swelling small, lying below and along posterior edge of orbit. Lateral extension of cervical groove deep, bounding posterior margin of subhepatic swelling, antennar groove extending ventral to subhepatic swelling. Branchiocardiac groove extending onto flank nearly parallel to cervical groove, curving forward to intersect cervical groove, swelling (omega?) just posterior to intersection of two grooves; postcervical groove extending onto flank and intersecting branchiocardiac groove at about midheight.

Pleural suture well defined, pterygostome well calcified, with two oblique swellings, rimmed.

Discussion: Glaessnerella is herein referred to Longodromitidae based upon its possession of deep augenrests and ornamentation; a narrow rostrum; well-defined cervical groove originating posterior to the orbits on the lateral margin; parallel lateral margins; well-developed cervical, branchiocardiac, and postcervical grooves; digitate projection on epibranchial region; short flanks dorsal to the pleural suture; and triangular subdorsal extension of the epibranchial region. It differs from other genera in possessing a postcervical groove that extends onto the flanks, in being about as long as wide, and in having very well calcified pterygostomial regions that are well-preserved. It is also distinct in having deep augenrests that are directed anterolaterally, such that they are very high and sometimes partially visible in dorsal view. Glaessnerella is very similar to Planoprosopon, with which it shares an intraorbital spine near the base of the rostrum, an anterolaterally directed outer-augenrest spine, and ornamented epibranchial region. However, species of Planoprosopon are longer overall, have a rostrum that is not directed dorsally, and have less anterolaterally directed augenrests. Similarities to Dioratiopus have already been discussed.

WRIGHT \& Collins (1972) referred several species to Glaessnerella. Most form a tight morphological group, similar to the type species. A few are outliers, mostly due to their poor preservation. Glaessnerella latteri is quite fragmentary, retaining the posterior portion of the carapace. 


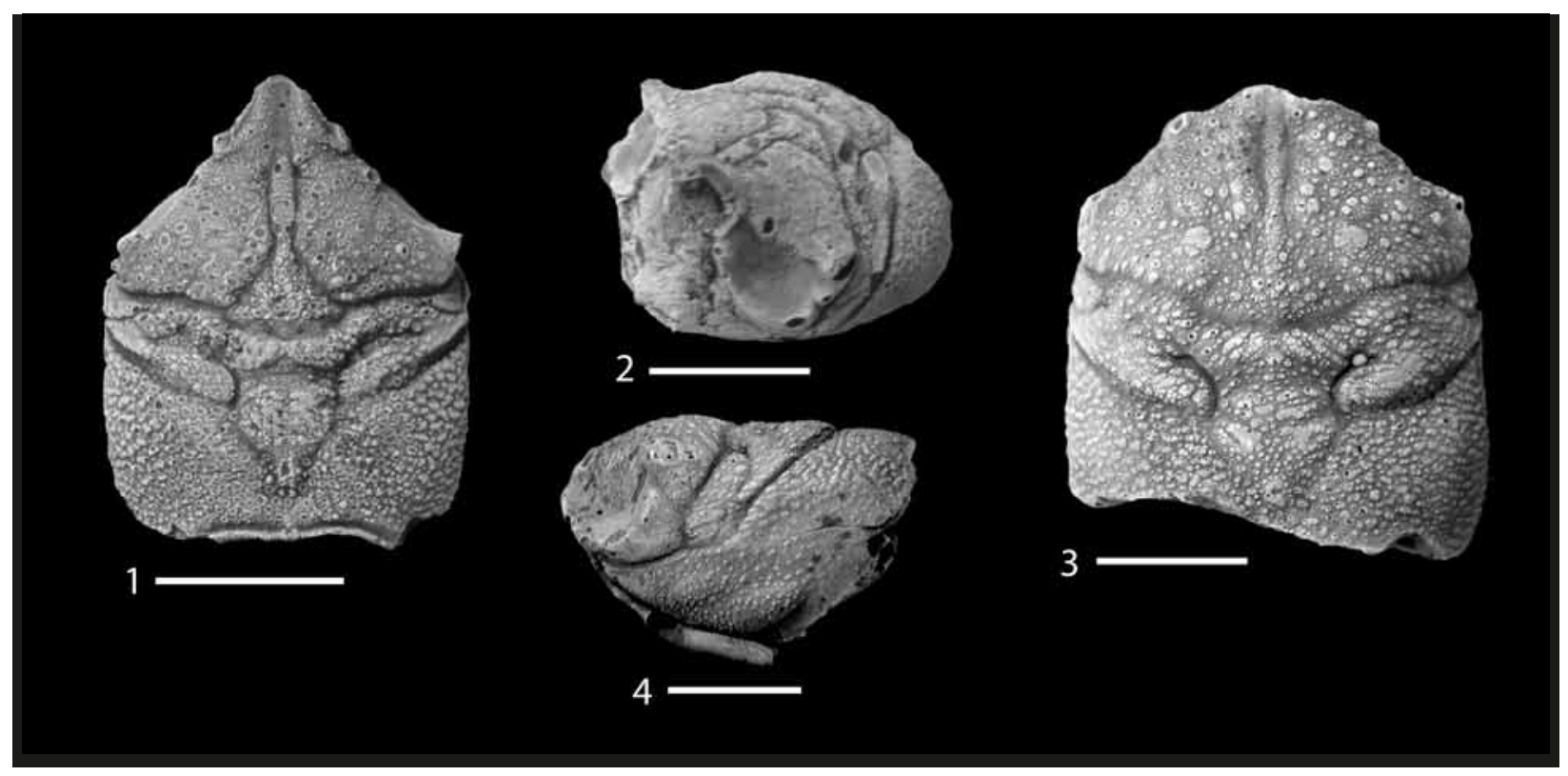

Fig. 3. Glaessnerella spinosa (VAN Straelen, 1936). 1-2 - cast of (BMNH) In. 60991 numbered KSU D 831, Kent, UK, Albian, dorsal carapace (1) and oblique orbital view (2); 3-4 - cast of J. S. H. Collins Collection \# 2425e numbered KSU D 1230 , Kent, UK, Albian, lateral view showing pleural suture and calcified pterygostome ventral to it. Scale bars $=0.5 \mathrm{~cm}$.

Glaessnerella angusta is much longer than wide, more reminiscent of Planoprosopon than Glaessnerella; however, the surface and frontal regions are poorly preserved. At this time we retain these species in the genus until more complete and better preserved specimens of each can be collected.

\section{Glaessnerella spinosa (VAN StRAelen, 1936)} Figs. 1.5-1.7, 3

1936 Homolopsis spinosa VAN Straelen, 1936, p. 33, pl. 4 , fig 5.

1972 Glaessneria spinosa (VAN STRAelen, 1936). Wright \& Collins, p. 36, pl. 4, figs. 1-6, text-fig. 6f-i.

1975 Glaessnerella spinosa (VAN STRAELEN, 1936). WRIGHT \& COLLINS, p. 441.

1980 “G.” spinosa (VAN Straelen, 1936). - Glaessner, p. 183.

1996 Dioratiopus spinosus (VAN Straelen, 1936). FraAYe \& COlLins, p. 326.

1996 Homolopsis spinosa VAn Straelen. - FraAye \& Collins, p. 323.

2010 D. [Dioratiopus] spinosa (VAn Straelen, 1936a). SchweITZER et al., p. 78.

Material examined: Glaessnerella spinosa, (BMNH) In. 60991 (figured in Wright \& Collins 1972: pl. 4, fig. 3a-c) and casts numbered KSU D 831; cast of JSHC 2425e numbered KSU D 1230.

Diagnosis: Rostrum strongly directed dorsally, tip downturned at right angle to dorsal surface; outer-augenrest spine long, directed laterally; pleural suture well-defined, pterygostome well-calcified, with two oblique swellings, rimmed.

Description: Carapace longer than wide, widening slightly posteriorly, widest in mid-branchial regions; flattened longitudinally, weakly vaulted transversely; flanks steep, perpendicular to dorsal surface.

Rostrum long, directed anteriorly and dorsally, with tip downturned perpendicular to remainder of rostral surface. Eyestalk apparently arising under rostrum, augenrest large, oblique; with inner and long outer supramarginal spines, small lower inner augenrest spine. Lateral margins overall straight; cervical groove incising margin a short distance from outer-augenrest spine; weak incision from discontinuous postcervical groove midway between cervical and weak branchiocardiac incision; margin posterior to branchiocardiac incision very long, rounding into wide, rimmed, axially concave posterior margin.

Mesogastric region well-defined, with long anterior process extending at least to base of rostrum, widened posteriorly. Protogastric and hepatic regions confluent, with a few large and many small granules. Metagastric region bilobed, narrow axially, widening laterally on each side, as wide as base of mesogastric region. Urogastric region short, narrow, depressed below level of metagastric and cardiac regions. Cardiac region triangular, apex directed posteriorly. Intestinal region poorly defined.

Cervical groove sinuous but overall concave forward, originating a short distance posterior to outer-orbital spine, deep. Postcervical groove discontinuous, composed of deep segment across axis and weaker arcuate convex forward segments positioned close to lateral margins connected 
to axial segment by discontinuous arc-like pits (Fig. 3.1). Branchiocardiac groove deep, composed of arc extending to anterior corner of cardiac region and continuing along margin of cardiac region.

Epibranchial region overall linear, directed at axial regions, with distinctive arcuate regions defined by postcervical groove and other grooves, digitate projection directed at anterior edge of cardiac region. Branchial regions long, broadly inflated, granular.

Subhepatic swelling small, lying below and along posterior edge of orbit. Lateral extension of cervical groove deep, bounding posterior margin of subhepatic swelling, antennar groove extending ventral to subhepatic swelling. Branchiocardiac groove extending onto flank nearly parallel to cervical groove, curving forward to intersect cervical groove, swelling just posterior to intersection of two grooves (omega?); postcervical groove extending onto flank and intersecting branchiocardiac groove at about midheight.

Pleural suture well-defined, pterygostome well-calcified, with two oblique swellings, rimmed.

Discussion: This species was originally described by VAN STRAELEN (1936) from the Albian of northeastern France. Wright \& Collins (1972) later reported several specimens from the Albian of southern UK. It is by far the best preserved species of the genus.

Measurements: Measurements (in $\mathrm{mm}$ ) taken on the dorsal carapace of specimens of Glaessnerella spinosa are presented in Table 2 .

\section{Genus Vespridromites nov.}

Type species: Dioratiopus hearttailensis BISHOP, 1985, by original designation.

Included species: Vespridromites dawsonensis (BISHOP, 1973), as Homolopsis; V. hearttailensis; Vespridromites scotti (Bishop, 1983), as Dioratiopus.

Etymology: The genus name is derived from the Latin word vesper, meaning evening or west, and the stem dromites, a common stem within the dromiacean crabs, in reference to the occurrence of the members of the genus in the Western Hemisphere, the western United States of America, and the Western Interior Seaway of North America. The gender is feminine.

Diagnosis: Carapace quadrate, slightly longer than wide or equant, widest in position of hepatic region just posterior to augenrests. Augenrests very broad, shallow, directed forward; with inner, outer, and subaugenrest spines; outeraugenrest spine directed anterolaterally. Male and female abdominal somites free, becoming progressively longer and wider toward telson; each somite with three swellings, axial and lateral; telson very long, twice as long as somite 6, extending well beyond coxae of pereiopod 1 .

Pereiopod 5 subdorsal, small.

Discussion: Vespridromites new genus is referable to Longodromitidae based upon its possession of broad augenrests with distinct ornamentation; a narrow rostrum; well-defined cervical groove originating posterior to the augenrests on the lateral margin; parallel lateral margins; well-developed cervical, branchiocardiac, and postcervical grooves; digitate projection on the epibranchial region; short flanks; and triangular subdorsal extension of the epibranchial region. Vespridromites differs from most other genera in the family in possessing a postcervical groove that extends onto the flanks and in being about as long as wide. It is quite similar to Dioratiopus and Glaessnerella; however, species of those two genera possess a well-calcified pterygostomial region. Two specimens of Vespridromites hearttailensis have wellpreserved flanks, appendages, and abdomina and do not appear to show evidence of a well-calcified pterygostomial region. Other differences include the position of maximum width in Vespridromites, which occurs in the hepatic region, whereas in species of Dioratiopus, the maximum width occurs in the epibranchial region and the width is maintained from the outer-orbital spine to the posterior corner. The cervical groove in Vespridromites extends in a straighter path across the carapace, whereas in Dioratiopus, it traverses the carapace in a V-shape. Vespridromites is similar to species of Planoprosopon in possessing nearly identical regional development, a carapace that can be widest at the hepatic region, and broad, forward directed orbits. Vespridromites spp. differ in being about as wide as long instead of longer than wide and possessing a postcervical groove that extends onto the flanks.

The type species of Vespridromites, $V$. hearttailensis, is by far the best preserved and known species of the genus. Vespridromites dawsonensis lacks well-preserved margins on most of the carapace, due to poor preservation. However, it does have a well-defined orbit and carapace regions that are nearly identical to those of $V$. hearttailensis. Vespridromites dawsonensis had originally been referred to Homolopsis, but GLAESSNER (1980) removed it to Dioratiopus based upon its lack of a linea homolica diagnostic for Homolopsis spp. It is best accommodated within Vespridromites due to its cardiac region extending to the posterior margin and deeply subdivided metagastric region, seen in $V$. hearttailensis and not Dioratiopus spp. Dioratiopus scotti BISHop, 1983, is fragmentary. We herein refer it to Vespridromites questionably, based upon its possession of similar carapace regions, what appear to be two small spines near the outer-orbital angle, and the large tubercles on the protogastric region. These features are similar to those of $V$. hearttailensis, although $V$. scotti lacks the deeply subdivided metagastric region of $V$. hearttailensis.

Vespridromites hearttailensis new combination possesses a configuration of the abdomen that appears to be unique among Dromiacea (Table 1). The abdomen extends well beyond the coxae of the first pereiopods, terminating between the third maxillipeds. The telson is much longer than wide, and the epimeres are short and poorly developed. The uropods are not visible. Only the fifth pereiopod appears to be reduced and subdorsal; the fourth is moderate in size. None of the sternum is visible in the female. The strong similarities of the dorsal carapace of Vespridromites spp. with Planoprosopon strongly indicate placement within Longodromitidae (Fig. 1), and the unique characteristics of the abdomen reinforce the fact that it cannot be placed 


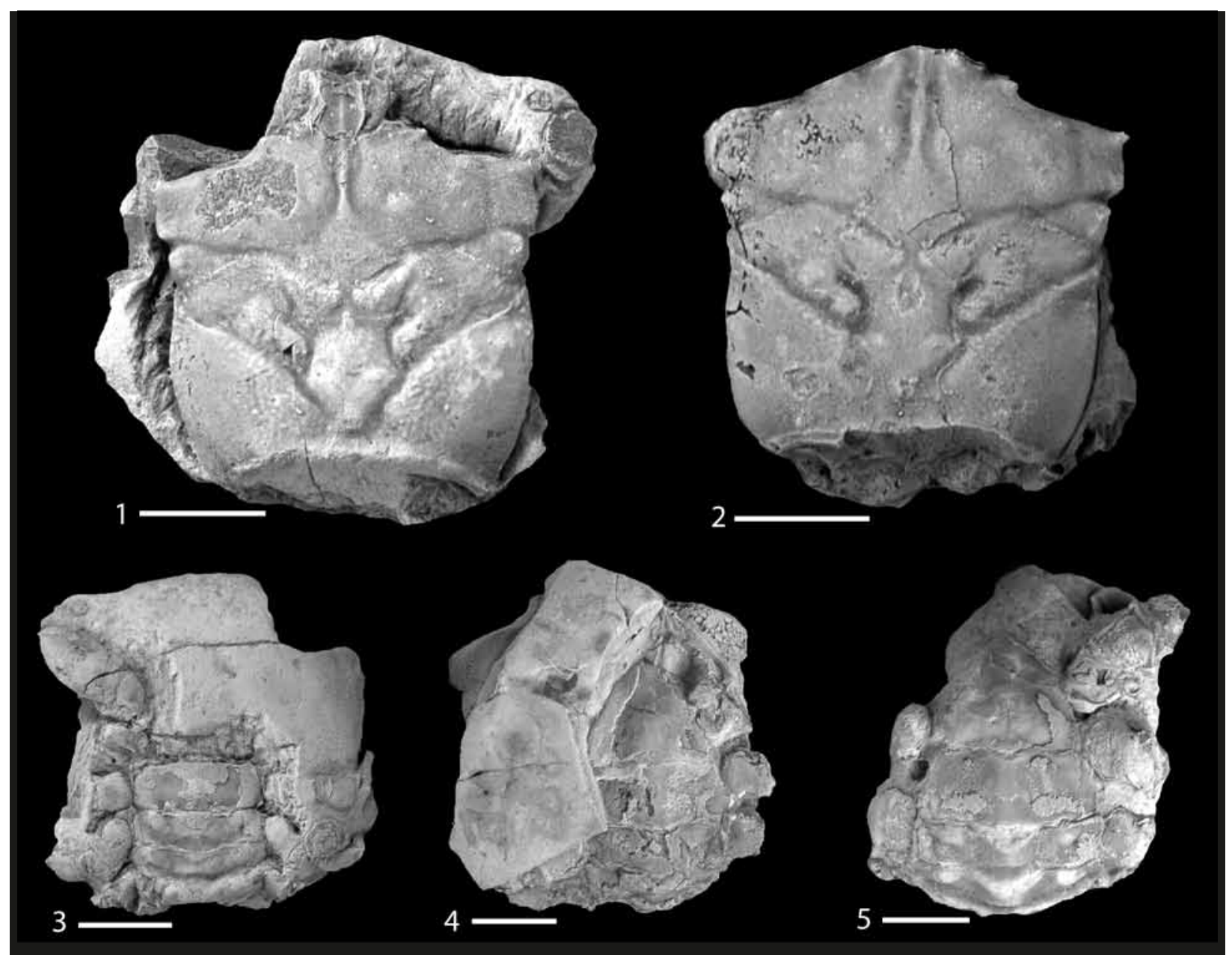

Fig. 4. Vespridromites hearttailensis (BISHOP, 1985) new comb. 1, 3 - SDSMT I3999, Belle Fourche, South Dakota, USA, Pierre Shale, Campanian, dorsal carapace (1) and male abdomen (3); 2, 5 - holotype, SDSM 10030, Butte County, South Dakota, Campanian, dorsal carapace (2) and female abdomen (5); 4 - paratype, SDSM 10031, paratype, Butte County, South Dakota, Campanian, female abdomen. Scale bars $=0.5 \mathrm{~cm}$.

in any other dromiacean family currently known to have preserved abdomina.

We debated as to whether or not this species possesses the well-calcified pterygostomial region as seen in Glaessnerella and Dioratiopus. Specimen SDSMT I3999 clearly shows a gap between the pleural suture and the pereiopods. Despite preparation attempts, we could find no evidence of cuticle material in this "gap." It is possible that it existed and was less well-calcified in this taxon. Because only three specimens of Vespridromites hearttailensis are known, more material will be needed to determine the nature of the pterygostome ventral to the pleural suture.

\section{Vespridromites hearttailensis (BISHOP, 1985) new comb. Fig. 4}

1985 Dioratiopus hearttailensis BisHop, p. 616.

1996 Dioratiopus hearttailensis BISHOP. - FrAAYE \& COLLINS, p. 326.
2010 Dioratiopus hearttailensis Bishop. - SchweItzer et al., p. 80 .

Material examined: SDSM 10030, holotype; SDSM 10031 paratype; SDSMT I3999 unnumbered.

Occurrence: The specimens were collected from the Heart Tail Ranch, Butte County, South Dakota, from early Campanian rocks.

Diagnosis: As for genus.

Description: Carapace quadrate, slightly longer than wide or equant, widest in position of hepatic region just posterior to augenrests; carapace flattened longitudinally, weakly vaulted transversely.

Front projected well beyond anterior margin of carapace, axially keeled, margins rimmed, tip strongly downturned so as to be perpendicular to dorsal surface. Eyestalks arising from below rostrum, long, well calcified. Augenrests 
very broad, shallow, directed forward; with inner, outer, and subaugenrest spines; outer-augenrest spine directed anterolaterally. Lateral margins sinuous, converging slightly posteriorly; notched at intersection of cervical and branchiocardiac grooves; short spine anterior to intersection of cervical groove with lateral margin, one swelling between intersection of cervical and branchiocardiac groove; remainder of lateral margin broadly convex, possibly with some granules. Posterior margin wide, concave, rimmed.

Mesogastric region with long anterior process extending as keel onto rostrum, widened posteriorly into triangular area. Protogastric region very wide, with 2 large swellings; hepatic region very small, quadrate. Metagastric region bilobed, constricted axially; Urogastric region narrow, with concave lateral margins; cardiac region triangular, large swellings at each apex, extending almost to posterior margin; intestinal region very short, poorly defined. Epibranchial region bilobed; small triangular lobe laterally, remainder including digitate projection. Remainder of branchial regions undifferentiated.

Cervical groove sinuous, extending from lateral margin in overall straight line to base of mesogastric region, arcing concave forward around base of mesogastric region. Postcervical groove continuous across axis, with discontinuous segments along lateral margins that intersect with cervical and branchiocardaic groove to form triangular portion of epibranchial region. Branchiocardiac groove first arcing concave forward, then arcing convex forward, then tracing outline of cardiac region.

Cervical groove and branchiocardiac groove extending onto flanks, parallel; branchiocardiac groove arcing anteriorly along ventral margin and merging with cervical groove. Subhepatic region poorly developed.

Male and female abdominal somites free, becoming progressively longer and wider toward telson; female somites wider and more inflated than those of male; each somite with three swellings, axial and lateral; telson very long, twice as long as somite 6 , extending well beyond coxae of pereiopod 1 .

Pereiopod 5 subdorsal, small.

Measurements: Measurements (in mm) taken on specimens of Vespridromites hearttailensis, with the holotype (SDSMT 10030) and SDSMT I3999 listed respectively. Maximum carapace width: 18.5, 15.4; carapace length (excluding rostrum): 19.4, 15.5; fronto-orbital width, 17.5, 15.1; rostral width (base): 3.4, 2.4 .

\section{Genus Antarctiprosopon nov.}

Type species: Homolodromia chaneyi FELDMANn \& WILSON, 1988, by original designation.

Etymology: The genus name is derived from Antarctica, the collecting locality, and Prosopon, a common stem used for extinct members of the podotreme crabs; the gender is neuter.

Diagnosis: Carapace rectangular, longer than wide, granular overall; cervical, postcervical, and branchiocardiac grooves deep; protogastric, metagastric, and cardiac regions ornamented with large swellings; lateral margins with granular rim.

\section{Description: As for species.}

Discussion: Antarctiprosopon chaneyi new combination was originally placed within Homolodromia A. MiLnEEDWARDS, 1880, based upon its quadrate carapace, deep grooves, and reduced pereiopods 4 and 5. Comparison of specimens of this species to various taxa within Longodromitidae demonstrate remarkable similarities in form. Thus, we refer the Antarctic specimens to a new genus and species within Longodromitidae. Antarctiprosopon new genus possesses all of the diagnostic features of Longodromitidae and differs from Homolodromiidae in possessing deep postcervical grooves, which Homolodromiidae lack. The grooves of Antarctiprosopon are much deeper than those seen in Homolodromiidae. Homolodromiidae are much higher vertically than Antarctiprosopon, which is dorsoventrally flattened. The abdominal somites of Antarctiprosopon are narrow and lack long epimeres, which are typical of homolodromiids. Unfortunately, the distal portion of the male abdomen is not exposed in the known specimens of Antarctiprosopon, making comparison with those of Homolodromiidae impossible. However, the similarities and differences listed here strongly indicate that Antarctiprosopon is a member of Longodromitidae.

Antarctiprosopon is most similar to Planoprosopon. Members of the two genera exhibit nearly identical regional development, ornamentation, development of augenrests and rostrum, and ornamentation of the flanks. They differ because Antarctiprosopon has wider, more inflated branchial regions, and the posterior margin of Antarctiprosopon is sinuous, with two convex elements, rather than broadly concave as in Planoprosopon.

\section{Antarctiprosopon chaneyi (FELDMANN \& WILSON, 1988) new combination}

Figs. 1.9-1.11, 5

1988 Homolodromia chaneyi FELdmann \& Wilson, p. 473, figs. 6-7.

1993 Homolodromia chaneyi Feldmann \& Wilson. Feldmann, p. 204.

1993 Homolodromia chaneyi FELdmann \& WiLson. Feldmann et al., p. 34.

1995 Homolodromia chaneyi Feldmann \& WiLson. Guinot, p. 266.

2004 Homolodromia chaneyi Feldmann \& Wilson. SCHWEITZER et al. p. 141.

2010 H. [Homolodromia] chaneyi FELdMANn \& WiLSON. Schweitzer et al., p. 58.

Material examined: Holotype, USNM 404870 and paratypes USNM 404871-74.

Occurrence: The specimens were collected from the Eocene La Meseta Formation, Seymour Island, Antarctica.

Diagnosis: As for genus. 


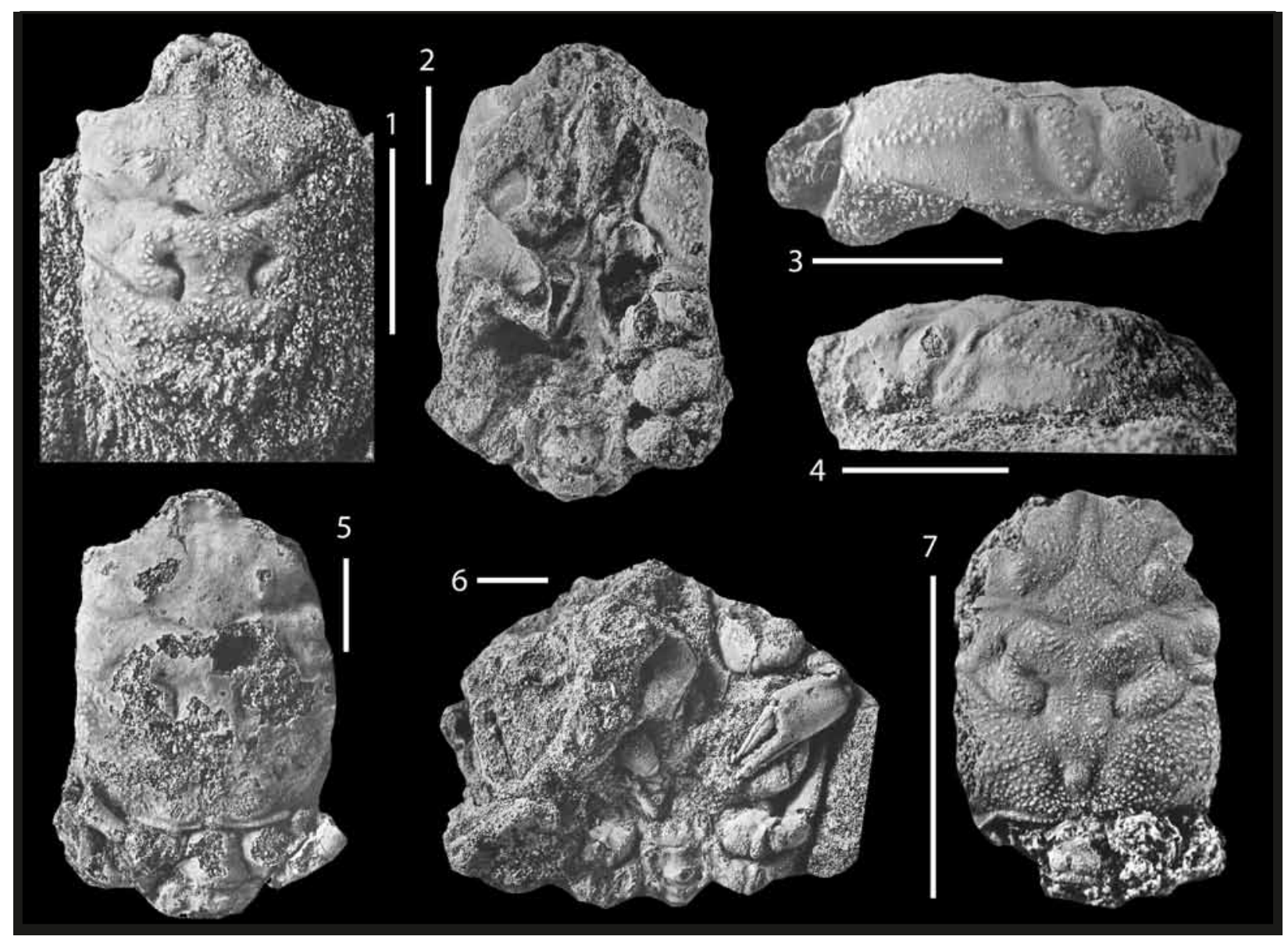

Fig. 5. Antarctiprosopon chaneyi (Feldmann \& Wilson, 1988) new combination, Seymour Island, Antarctica, Eocene La Meseta Formation. 1, 4 - paratype USNM 404872, dorsal carapace (1) and lateral views (2); 2, 5 - holotype USNM 404870, ventral (2) and dorsal carapace view showing dorsally visible abdominal somites 1 and 2 and subdorsal pereiopod 5 (5); 3 paratype USNM 404871, lateral view; 6 - paratype USNM 404874, ventral view showing chelipeds and abdominal somites; 7 - paratype USNM 404873, well-preserved dorsal carapace with dorsally visible abdominal somite 1.

Description: Carapace rectangular, longer than wide widest in branchial region; flattened transversely and longitudinally; regions moderately defined by grooves.

Rostrum appearing to be axially sulcate, eyestalk arising under rostrum, augenrest deep, smooth, possibly with an intra-orbital augenrest and with small outer-augenrest spine. Lateral margins parallel, deeply incised where intersected by cervical and branchiocardiac grooves; with weak spine anterior to cervical groove and larger spine between grooves; margin ridged posterior to branchiocardiac groove; posterior margin rimmed, with a concavity on either side of axis.

Mesogastric region with long anterior process, terminating at base of rostrum, widened posteriorly. Protogastric region with longitudinal inflation parallel to mesogastric anterior extension; hepatic region wider than long, with two spherical swellings. Metagastric region wide, urogastric region depressed, short, cardiac region with long posterior process, intestinal region flattened. Epibranchial region with lateral swelling which extends into the lateral spine, ridge anterior to branchiocardiac groove, digitate extension directed at cardiac region. Remainder of branchial region undifferentiated, granular.

Cervical groove deep, extending in nearly straight lines toward axis. Postcervical groove straight, continuous across axis, connecting to branchiocardiac groove with arcuate grooves bounding lateral margins of urogastric region. Branchiocardiac groove deep laterally, more or less parallel to cervical groove, becoming weaker as it curves around the cardiac region.

Flanks short, maintaining uniform height along entire length. Subhepatic swelling short, small. Cervical groove extending onto flank almost perpendicular to dorsal surface; branchiocardiac groove extending onto flank at oblique angle, intersecting cervical groove and extending ventral to subhepatic region as antennar groove; omega area weakly inflated.

Sternum narrow; sternites 1-3 long; sternite 4 with long anterior process, episternal projection posteriorly for articulation with P1. Male abdominal somites narrow, with transverse ridges. 


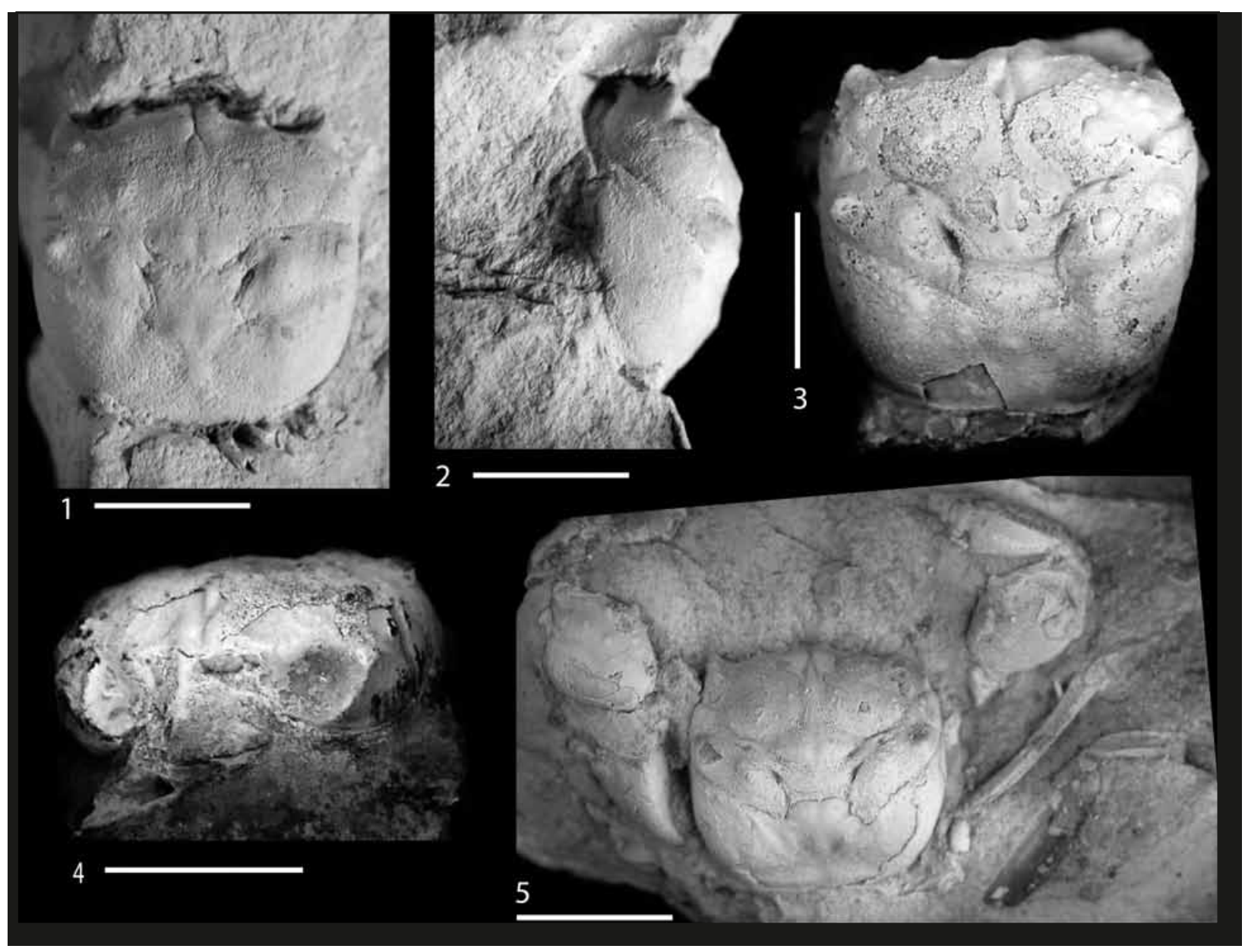

Fig. 6. Torynomma quadrata Woods, 1953, Queensland, Australia, Albian. All specimens part of the originally described series. 1, 2 - holotype, QMF2877, dorsal carapace (1) and lateral view (2); 3, 4 - QMF2880, dorsal carapace (3) and anterior view showing orbits (4); 5 - UQF14924, dorsal carapace and pereiopods. Scale bars =1 cm.

Measurements: Measurements (in $\mathrm{mm}$ ) taken on the dorsal carapace of Antarctiprosopon chaneyi are presented in Table 3.

\section{Family Homolodromiidae Aьсоск, 1900}

\section{Genus Notiodromia nov.}

Type species: Torynomma (Torynomma) australis FELDMANn, Tshudy \& Thomson, 1993, by original designation.

Other species: Notiodromia novaezelandica (FELdmann, 1993), as Homolodromia.

Etymology: The genus name is derived from the Greek word notios, meaning southern, and the generic stem Dromia, a common stem used within Dromiacea, denoting the occurrence of both species of the genus in the high southern latitudes. The gender is feminine.
Diagnosis: Carapace longer than wide, widening distally, granular overall; rostrum with two sharp lateral rostral spines; augenrest wide, concave, with sharp outer-augenrest spine, directed forward or weakly anterolaterally; mesogastric region and metagastric regions well marked; urogastric and cardiac regions confluent; cervical, postcervical and branchiocardiac grooves deep, extending onto flank of carapace; posterior margin biconcave; subhepatic region inflated; sternum narrow, sternites 4 and 5 long; first pereiopod short, chela long, slender.

Discussion: Feldmann (1993) referred a Cretaceous specimen from New Zealand to Homolodromia, H. novaezelandica, and Feldmann et al. (1993) referred another Cretaceous specimen, this time from Antarctica, to Torynomma (Torynomma) australis. We concur with the placement of the former species within Homolodromiidae, based upon its possession of a pair of lateral rostral spines, a carapace that widens distally and has rounded, convex branchial regions, and subparallel cervical and branchiocardiac grooves. These are typical of extant homolodromiids. Homolodro- 
mia novaezelandica differs from modern homolodromiids in being rather short in lateral view; however, this could be due to the lack of preservation of the uncalcified flank that is seen in extant homolodromiids. It also possesses deep grooves, a deep postcervical groove, and distinctive granular ornamentation overall. Extant homolodromiids do not have deep grooves, although they are developed, and lack well-developed postcervical grooves. In extant forms, the postcervical groove is very weak (see illustrations in GuINOT 1995). Extant homolodromiids lack granular ornamentation and are instead relatively smooth with short setae.

The specimen from Antarctica that was referred to Torynomma is nearly identical in terms of dorsal carapace ornamentation to those from New Zealand, as originally noted (FELDMANN et al. 1993: 35) although the extreme distortion of the branchial region by a bopyrid isopod makes interpretation of the fossil difficult. In addition, the Antarctic specimen possesses part of the sternum, which is narrow. Sternite 4 has episternal projections articulating with the coxae of pereiopod 1, and sternite 5 appears to be long and with a swelling centrally. This is quite different from the configuration of the sternum of Torynomma discussed below and more similar to those of Dromiacea (SCHWEITZER \& Feldmann 2010b). The Antarctic specimens also possess the augenrest structures protected by spines, the inflated subhepatic region, and long slender chelae on what appear to be short first pereiopods as seen in extant homolodromiids (Schweitzer \& Feldmann 2008 [imprint 2007]: pl. 1A).

Based upon these data, we refer the New Zealand taxon Homolodromia novaezelandica and the Antarctic specimen Torynomma australis to a new genus, Notiodromia, resulting in two new combinations, Notiodromia australis and Notiodromia novaezelandica. The preponderance of the evidence strongly indicates placement of this genus within Homolodromiidae, based upon dorsal carapace, sternal, and pereiopod morphology. The genus occurs in the early-late Campanian of Antarctica and the Maastrichtian of New Zealand (Feldmann et al. 1993; Feldmann 1993).

\section{Family Torynommidae GLAESSNER, 1980}

Included genera: Torynomma WooDs, 1953; Withersella Wright \& Collins, 1972 (questionably).

Diagnosis: Carapace quadrate; front narrow; orbits extremely broad, forward-directed, with short intraorbital spine and stout, forward directed outer-orbital spine; orbits and frontal margin of carapace nearly straight; cervical groove with hepatic groove extending anteriorly and inter- secting lateral margin, branchiocardiac groove subparallel to cervical groove and hepatic groove; branchiocardiac groove extending onto flank in long, anteroventral path; cervical groove weakly extending onto flank and appearing to nearly intersect branchiocardiac groove; hepatic groove appearing to extend onto flank; sternite 4 broadly trapezoidal, with arcuate transverse ridge against which female abdomen terminates; abdominal somites of female wide, with long epimeres on somites 3-6; telson much wider than long, terminating before coxae of first pereiopods, abdomen appearing to rest in sterno-abdominal cavity; female gonopore coxal; pereiopods 4 and 5 very reduced.

Etymology: Collins et al. (1995: 200) corrected the family name to Torynommatidae. Our reading of the International Code of Zoological Nomenclature (1999) does not reveal any need to have done so. Thus, we retain usage of the original Torynommidae as used by GLAESSNER (1980).

Discussion: The diagnosis is based upon Torynomma, the nominate genus. It is clearly a podotreme, based upon the position of the female gonopore; however, its superfamily placement is not clear at this time. In Torynomma, sternite 4 is broad, with long episternal projections which may be directed vertically, and it has an arcuate transverse ridge at which the female abdomen terminates. A small portion of sternite 3 is visible anterior to sternite 4 . The abdominal somites of the female are wide, with long epimeres, and the telson is much wider than long. The abdomen terminates before the coxae of the first pereiopods (GLAESSNER 1980, fig. 11).

This combination of characteristics is unique among the podotrematous crabs (Table 1). GLAESSNER (1980) had commented that the sternum of Torynomma was most similar to those of Cyclodorippinae OrTMAnN, 1892, and Homolidae DE HAAN, 1839, and this seems to be the case so far as is known. Of all of the podotrematous groups, Torynomma seems most similar to members of Homoloidea DE HAAN, 1839 , in having a broad sternum and abdominal somites with long epimeres. Within Homolidae and Poupiniidae Guinot, 1991, the abdomen in males and females reaches to a position between the third maxillipeds and does not terminate posterior to the coxae of the first pereiopods. It differs from Homolidae in having both pereiopods 4 and 5 reduced, whereas homolids generally only have pereiopods 5 reduced. Latreillidae STIMPSON, 1858, generally have very long slender pereiopods, whereas those of Torynomma are short and stout. Within Cyclodorippoidea OrTMAnN, 1892, the abdomen lies in a deeply excavated sterno-abdominal cavity; there is no evidence of such a cavity in Torynomma.

Table 3. Measurements (in mm) taken on the dorsal carapace of Antarctiprosopon chaneyi (FELDMANN \& WILSON, 1988).

\begin{tabular}{llllll}
\hline Specimen Number & Length & Width & Rostral width & $\begin{array}{l}\text { Fronto-orbital } \\
\text { Width }\end{array}$ & $\begin{array}{l}\text { Length to Max } \\
\text { Width }\end{array}$ \\
\hline $\begin{array}{l}\text { USNM 404870 } \\
\text { (Holotype) }\end{array}$ & 33.5 & 29.3 & - & 23.6 & 23.7 \\
USNM 404871 & 20.4 & 17.6 & - & 14.6 & 14.0 \\
USNM 404872 & 16.2 & 14.6 & 4.6 & 14.0 & 12.3 \\
\hline
\end{tabular}




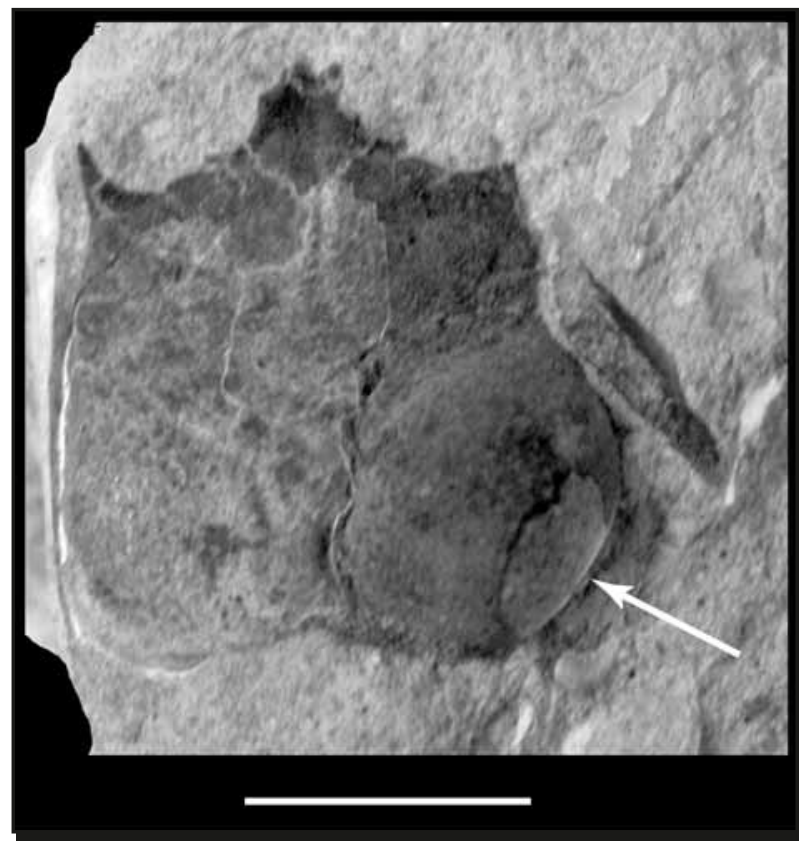

Fig. 7. Withersella crepitans WRight \& Collins, 1972, Isle of Wight, UK, Aptian, BMNH IC15. Notice large swelling (arrow) in right branchial chamber, probably from a bopyrid isopod. Scale bar $=0.5 \mathrm{~cm}$.

The sternum and abdomen of Torynomma are quite different than those of taxa herein referred to Longodromitidae. In Vespridromites hearttailensis new combination, the female abdomen extends well beyond the coxae of the first pereiopods, terminating between the third maxillipeds. The telson is much longer than wide, and the epimeres are short and poorly developed. None of the sternum is visible in the female. Thus, we are certain that Torynommidae is quite distinct, and that Dioratiopus and related taxa are not referable to it.

\section{Genus Torynomma Woods, 1953}

Type species: Torynomma quadrata Woods, 1953, by original designation.

Included species: Torynomma dentatum GLAESSNER, 1980; T. flemingi GLAESSNER, 1980; questionably T. planata FELDMANN, 1993; T. quadrata.

\section{Torynomma quadrata Woods, 1953} Fig. 6

Material examined: QMF2877, holotype; QMF 2880, paratype, uqf14924.

Occurrence: Early Cretaceous (Albian) of Queensland, Australia; Late Cretaceous (Cenomanian - Turonian), Northern Territory, Australia; Late Cretaceous (Maastrichtian) of New Zealand.
Diagnosis: Carapace quadrate; front narrow; orbits extremely broad, forward-directed, with short intraorbital spine and stout, forward directed outer-orbital spine; orbits and frontal margin of carapace nearly straight; cervical groove with hepatic groove extending anteriorly and intersecting lateral margin, branchiocardiac groove subparallel to cervical groove and hepatic groove; branchiocardiac groove extending onto flank in long, anteroventral path; cervical groove weakly extending onto flank and appearing to nearly intersect branchiocardiac groove; hepatic groove appearing to extend onto flank; anterior sternite, probably 4, broad, with long episternal projections, with transverse ridge at which female abdomen terminates; abdominal somites of female wide, with moderately developed epimeres; telson much wider than long, terminating before coxae of first pereiopods; at least pereiopod 5 appearing to have been reduced, subdorsal.

Discussion: Several species have been referred to Torynomma over the past half-century. The two species named by GlaESSNER (1980) appear to conform to the general features of the type species and therefore remain in the genus. Torynomma australis is here removed to Notiodromia. Bishop (1983) referred some claws from North America to Torynomma densus, apparently based on their possession of a spine on the proximal upper surface which the type species Torynomma may also possess, at least as drawn by Woods (1953: fig. 3). However, the claws described by BisHop (1983) have a more rectangular overall shape and more slender fingers than do those of Torynomma quadrata. The fragmentary nature of BISHOP's material makes it difficult to assign them to a genus; nevertheless, the difference in shape indicates that they are not a species of Torynomma. Torynomma planata, from the Cretaceous of New Zealand, is a tiny specimen that bears some similarities with other species of Torynomma including the quadrate shape and the development of carapace grooves and regions. It appears to have a much narrower fronto-orbital width than do species of Torynomma. We suggest two possibilities. One is that it may be a juvenile of Torynomma flemingi, also known from New Zealand. The other is that it may be a member of Cyclodorippoidea, because it bears similarities to Xeinostoma STEBbing, 1920, and other members of the superfamily in its size and shape. For now, we questionably refer it to Torynomma, as that referral does not extend the geologic or geographic range of the genus.

\section{Genus Withersella WRIGHT \& COLLINs, 1972}

Type and only species: Withersella crepitans WRIGHT \& Collins, 1972, by original designation.

Withersella crepitans WRIGHT \& COLLINS, 1972 Fig. 7

Material examined: (BMNH) IC15.

Occurrence: Early Cretaceous (Aptian) of Britain. 
Table 4. Species reassigned herein and their age and geographic range.

\begin{tabular}{|c|c|c|c|c|}
\hline Taxon & $\begin{array}{l}\text { Current Generic } \\
\text { Placement }\end{array}$ & $\begin{array}{l}\text { Current Family } \\
\text { Placement }\end{array}$ & Age & Geographic Range \\
\hline $\begin{array}{l}\text { Dioratiopus } \\
\text { hearttailensis }\end{array}$ & $\begin{array}{l}\text { Vespridromites } \\
\text { hearttailensis }\end{array}$ & Longodromitidae & Campanian & South Dakota \\
\hline $\begin{array}{l}\text { Homolopsis } \\
\text { dawsonensis }\end{array}$ & $\begin{array}{l}\text { Vespridromites } \\
\text { dawsonensis }\end{array}$ & Longodromitidae & Maastrichtian & Montana \\
\hline Dioratiopus scotti & Vespridromites? scotti & Longodromitidae & Albian & Texas \\
\hline Dioratiopus primitivus & Coelopus primitivus & Longodromitidae & $\begin{array}{l}\text { Latest Tithonian - } \\
\text { earliest Berriasian }\end{array}$ & United Kingdom \\
\hline Homolodromia chaneyi & $\begin{array}{l}\text { i Antarctiprosopon } \\
\text { chaneyi }\end{array}$ & Longodromitidae & Eocene & Antarctica \\
\hline Torynomma australis & Notiodromia australis & Homolodromiidae & Campanian & Antarctica \\
\hline $\begin{array}{l}\text { Homolodromia } \\
\text { novaezelandica }\end{array}$ & $\begin{array}{l}\text { Notiodromia } \\
\text { novaezelandica }\end{array}$ & Homolodromiidae & Maastrichtian & New Zealand \\
\hline Binkhorstia ubaghsi & Binkhorstia ubaghsi & Longusorbiidae & Maastrichtian & Netherlands \\
\hline
\end{tabular}

Diagnosis: Carapace tiny, quadrate, transversely and longitudinally flattened; length and width about equal; rostrum axially sulcate, bilobed, margins upturned, node along midlength of margins; orbits appear to have a fissure, outer-orbital spine very long, directed forward and upward; fronto-orbital width 85 percent maximum carapace width. Mesogastric region long; anterior process very long, narrow, terminates at base of rostrum; hepatic and protogastric regions weakly distinguished; metagastric region well-defined by cervical and postcervical grooves; cardiac region with three nodes; epibranchial region extending onto flanks, dorsally separated into three parts by transverse grooves; remainder of branchial region weakly inflated, pustulose. Cervical groove sinuous, deepest around base of mesogastric region; postcervical groove deep, continuous; branchiocardiac groove deep.

Discussion: Withersella is known only from the type species (Fig. 7). The specimens are not well-preserved, so that detailed description is not possible. Details of the sternum and abdomen are not preserved. There are some important differences between Withersella and Torynomma, including a fissured orbit in Withersella; a postcervical groove in Withersella instead of the hepatic groove as in Torynomma; and the more ornamented epibranchial region seen in Withersella as compared to Torynomma. However, because the specimens of Withersella are not well preserved and lack ventral portions of the carapace, we elect to retain it in Torynommidae at this time.

Subsection Heterotremata GuINOT, 1977

Superfamily Portunoidea RAFINESQUe, 1815

Family Longusorbiidae KARASAWA, SchweITZER \& FELDMANN, 2008

Genus Binkhorstia NoETLING, 1881
Type species: Dromilites ubaghsi VAN BINKHORST, 1857, by monotypy.

Included species: Binkhorstia euglypha Collins et al., 1995; B. ubaghsii (VAN BINKHORST, 1857).

Binkhorstia ubaghsii (vAN BINKHORST, 1857)

Fig. 8

Material examined: ODG specimen.

Diagnosis: Carapace square, transversely and longitudinally flattened. Front narrow proximally, widening distally, steeply downturned distally, rimmed, axially sulcate. Fronto-orbital width about 80 percent maximum carapace width; orbits directed forward, upper orbital margin biconcave, inner concavity with upturned rim; outer concavity with two shallow fissures; outer-orbital spine large, directed forward; lower orbital margin smooth, visible in dorsal view. Anterolateral and posterolateral margins confluent; posterolateral corner and posterior margin with rim; posterior margin weakly concave. Regions well defined. Mesogastric region well-defined posteriorly, lateral margins concave, anterior process indistinct. Protogastric regions with medial tubercle; hepatic region bilobed, weakly elevated, with lateral and central tubercles. Cervical groove concave forward around base of mesogastric region, then curving convex forward to lateral margin. Metagastric region narrow axially, inflated laterally; cardiac region pentagonal, apex directed posteriorly, with two transversely arranged tubercles. Epibranchial region ovate; mesobranchial region transverse, arcuate around posterior margin of epibranchial, widest axially; metabranchial region large, granular, with medial spines at level of cardiac tubercles, indistinguishable from intestinal region. Male sternum circular, widest at sternite 5; sternites 1-3 fused with an incomplete notch between 3/4; sternite 4 widening posteriorly, with triangular axial depression forming beginning of straight sided sterno-abdominal cav- 


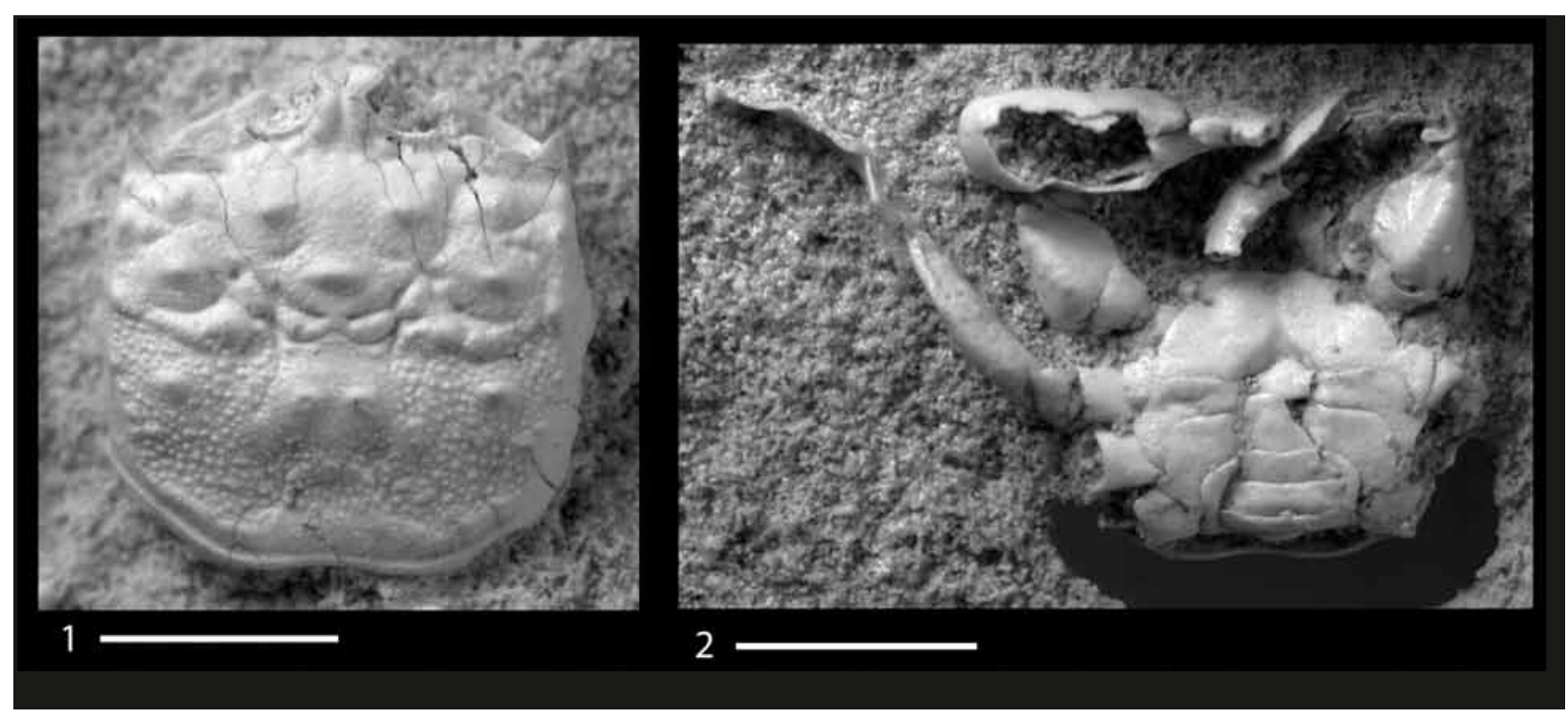

Fig. 8. Binkhorstia ubaghsi (VAN BInKhORST, 1857), ODG specimen. 1, 2 - dorsal carapace (1) and ventral surface showing sternum and male abdomen with all somites free (2). Scale bars $=0.5 \mathrm{~cm}$.

ity; sternite 8 apparently not visible in ventral view. Male abdominal somites free, appearing to completely fill space between coxae of fifth pereiopods.

Discussion: Examination of an excellently preserved specimen of Binkhorstia ubaghsii (Fig. 8) indicates that it cannot be aligned with Torynomma within Torynommidae. In Torynomma, the anterior sternite, probably 4, is broad, with long episternal projections, and has a transverse ridge at which the female abdomen terminates. In addition, the abdominal somites of the female are wide, with what appear to be moderately developed epimeres, and the telson is much wider than long, and the abdomen terminates before the coxae of the first pereiopods. These features, especially the development of epimeres, are suggestive of podotrematous or more primitive crabs, and indeed, Torynomma is a podotreme. The sternal architecture of Binkhorstia, including the ovate overall shape, well-developed sternites and episternal projections, and triangular, narrow, male abdomen with all somites free suggests placement within the heterotrematous crabs, possibly Portunoidea.

Among Portunoidea, the best possible placement seems to be within Longusorbiidae. Binkhorstia possesses many of the diagnostic features of the family, including a front that can be interpreted as lying between the interior-most orbital notches; a long, spatulate rostrum with a strongly downturned tip; very broad, sinuous, notched orbits; a fronto-orbital width that is about equal to the maximum carapace width; short gastric regions and long branchial regions; sternites 1 and 2 fused; sternal suture 3/4 developed as a notch laterally; sternite 4 long; sternal sutures $4 / 5$ and $5 / 6$ not parallel; sternite 8 not visible in ventral view; and all male abdominal somites free. However, there are some significant differences between Binkhorstia and the only other known genus within Longusorbiidae, Longusorbis
RICHARDS, 1975, upon which the family diagnosis is based. The male abdomen does not seem to fill the entire space between the coxae of the fifth pereiopods in Binkhorstia, and the overall carapace shape and ornamentation is different in Binkhorstia than in Longusorbis. Thus the placement of Binkhorstia within Longusorbiidae must be considered provisional at this time. Binkhorstia had previously been referred to Carcineretidae Beurlen, 1930 (Collins et al. 1995); however, in that family, male abdominal somites 3-5 are fused. Possibly Binkhorstia warrants its own family.

\section{Discussion}

The revisions herein are numerous and are summarized in Table 4. The referral of Antarctiprosopon to Longodromitidae extends the range of the family into the Eocene and to the high southern latitudes (Figs. 9.1, 10). High latitude settings have previously been hypothesized to have been refugia for taxa that survived the end-Cretaceous event(s) (SCHWEITZER \& FELDMAnn 2005). We also note that Homolodromiidae exhibits a disjunct temporal occurrence based on the known fossils referred to the family (Fig. 9.2). The latter strongly suggests that so-called Lazarus taxa are quite often simply those taxa with an incomplete fossil record, nothing more. Many decapod groups would exhibit such occurrences based upon their fossil records. We also note that the highest diversity interval for Longodromitidae is the Late Jurassic (Fig. 9.1), with secondary pulses in the middle and Late Cretaceous. Investigation into these patterns is ongoing. 


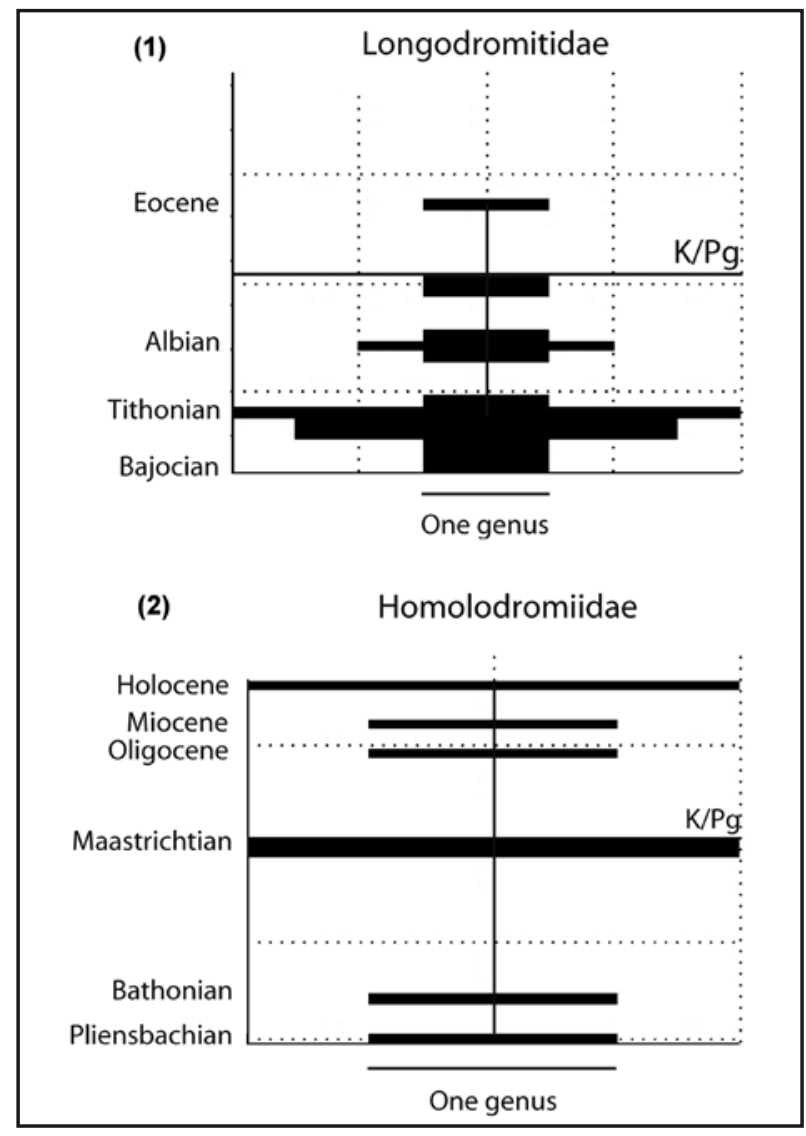

Fig. 9. Spindle diagrams of total number of genera occurring per stage for Longodromitidae (1) and Homolodromiidae (2). Note disjunct temporal occurrences in both families. Diagram generated by PAST (HAMMER et al. 2001) using data from Schweitzer et al. (2010).

\section{Acknowledgments}

Dr. A. Cook, Queensland Museum, Australia, generously took the photos of Dioratiopus and Torynomma. C. Melish and M. MunT arranged our visit to The Natural History Museum, London. J. Thompson, United States National Museum of Natural History, Smithsonian Institution, arranged our visit to the collections there. M. RILEY accommodated our visit to the Sedgwick Museum, Cambridge. R.H.B. FraAiJe facilitated our visit to the Oertijdmuseum De Groenepoort, Boxtel, The Netherlands. S. Shelton and J. Martin loaned specimens and permitted our extensive search through the collections at the South Dakota School of Mines and Technology, Rapid City, South Dakota. R.L.M. Ross, British Columbia, donated the specimen of Longusorbis. Our work has been greatly informed by work in museums throughout continental Europe, especially the Natural History Museum of Vienna, thanks to M. Harzhauser, A. KroH, and O. Schultz. The manuscript benefitted from reviews by F.R. Schram, Burke Museum, University of Washington, Seattle, USA, and G. Schweigert, Staatliches Museum für Naturkunde, Stuttgart, Germany. This research was funded by NSF EF-0531670 to FELDMANN and SchweITZER.

\section{References}

Alcock, A. (1900a): Materials for a carcinological fauna of India, 5: The Brachyura Primigenia or Dromiacea. - Journal of the Asiatic Society of Bengal, 68 (2) (3): 123-169.

Beurlen, K. (1930): Vergleichende Stammesgeschichte Grundlagen, Methoden, Probleme unter besonderer Berücksichtigung der höheren Krebse. - Fortschritte in der Geologie und Paläontologie, 8: 317-586.

Beurlen, K. (1932): Brachyurenreste aus dem Lias von Bornholm mit Beiträgen zur Phylogenie und Systematik der Brachyuren Dekapoden. - Paläontologische Zeitschrift, 14: 52-66.

Bishop, G.A. (1973): Homolopsis dawsonensis: a new crab (Crustacea, Decapoda) from the Pierre Shale (Upper Cretaceous, Maastrichtian) of Cedar Creek Anticline, eastern Montana. - Journal of Paleontology, 47 (1): 1920.

Bishop, G.A. (1983): Fossil decapod crustaceans from the Lower Cretaceous, Glen Rose Limestone of central Texas. - Transactions of the San Diego Society of Natural History, 20: 27-55.

Bishop, G.A. (1985): Fossil decapod crustaceans from the Gammon Ferruginous Member, Pierre Shale (Early Campanian), Black Hills, South Dakota. - Journal of Paleontology, 59 (3): 605-624.

Carter, J. (1898): A contribution to the palaeontology of the decapod Crustacea of England. - The Quarterly Journal of the Geological Society of London, 54: 15-44.

Collins, J.S.H., FraAYe, R.H.B. \& Jagt, J.W.M. (1995): Late Cretaceous anomurans and brachyurans from the Maastrichtian type area. - Acta Palaeontologica Polonica, 40 (2): $165-210$.

De Haan, W. (1833-1850): Crustacea. - In: Siebold, P.F. von (Ed.): Fauna Japonica sive Descriptio Animalium, quae in Itinere per Japoniam, Jussu et Auspiciis Superiorum, qui summum in India Batava Imperium Tenent, Suscepto, Annis 1823-1830 Collegit, Notis, Observationibus et Adumbrationibus Illustravit: i-xvii, i-xxxi, ix-xvi, 1-243, pls. A-J, L-Q, 1-55, circ. tab. 2; Lugduni Batavorum [= Leyden] (J. Müller et Co.).

Étallon, A. (1861): Notes sur les Crustacés Jurassiques du bassin du Jura. - Mémoires de la Societé de l'Agriculture, des Sciences et Lettres de la Haute Saône, 9: 129-171.

Feldmann, R.M. (1993): Additions to the fossil decapod crustacean fauna of New Zealand. - New Zealand Journal of Geology and Geophysics, 36:201-211.

Feldmann, R.M., Tshudy, D.M. \& Thomson, M.R.A. (1993): Late Cretaceous and Paleocene decapod crustaceans from James Ross Basin, Antarctic Peninsula. - The Paleontological Society Memoir, 28: i-iv, 1-41.

Feldmann, R.M. \& Wilson, M.T. (1988): Eocene decapod crustaceans from Antarctica. - In: Feldmann, R.M. \& Woodburne, M.O. (Eds.): Geology and paleontology of Seymour Island, Antarctic Peninsula. - Geological Society of America, Memoir, 169: 465-488.

FraAye, R.H.B. \& Collins, J.S.H. (1996): Two new decapod crustaceans from the Portlandian of Dorset, England. Proceedings of the Geologists' Association, 107: 323326. 

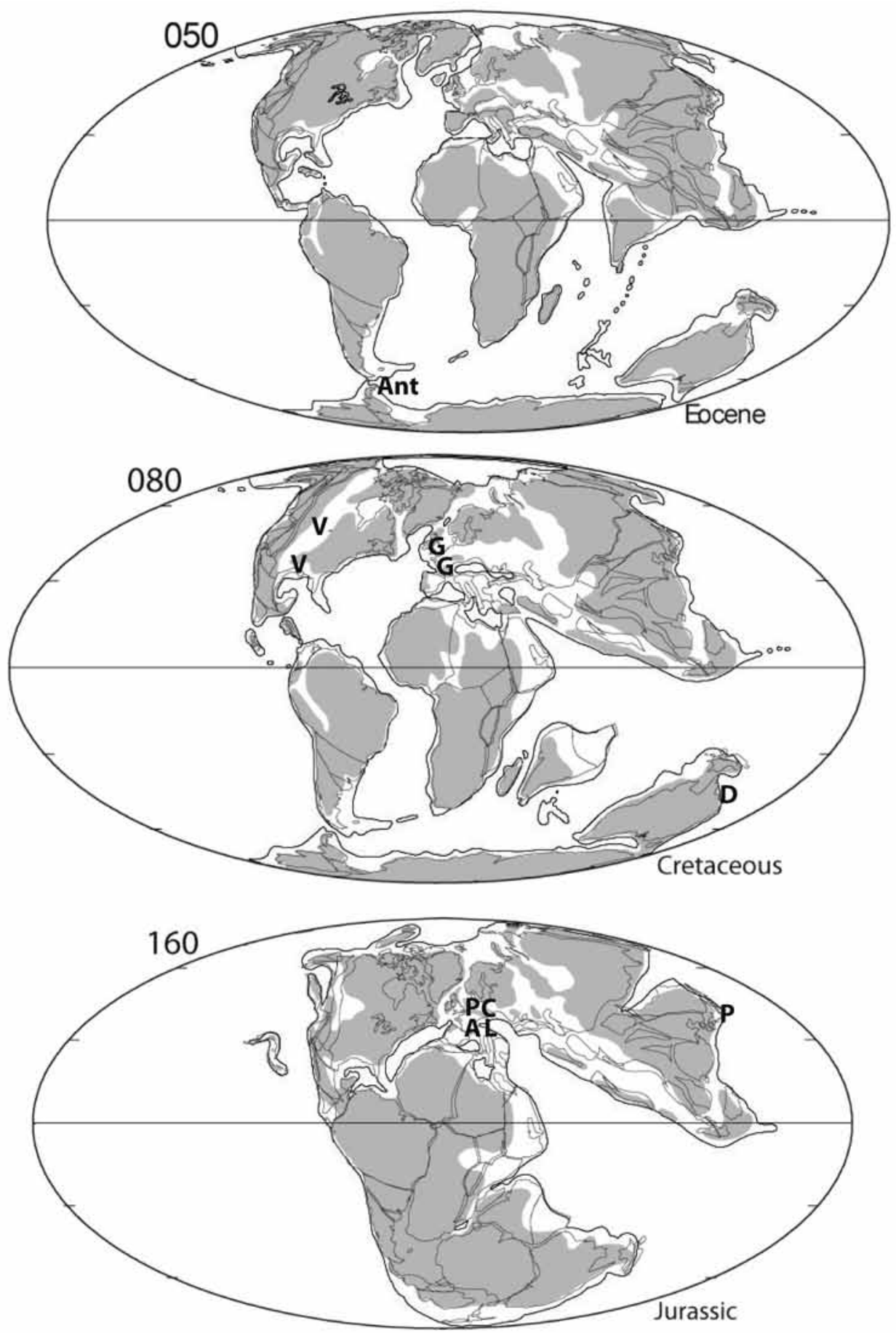

Fig. 10. Paleogeographic occurrence of Longodromitidae through time. Jurassic European occurrences designate all European occurrences for that genus, which may include several species and localities. $\mathrm{P}=$ Planoprosopon $\mathrm{spp}$.; $\mathrm{C}=$ Coelopus spp.; $\mathrm{A}=$ Abyssophthalmus spp.; $\mathrm{L}=$ Longodromites $\mathrm{spp} . ; \mathrm{G}=$ Glaessneropsis $\mathrm{spp} . ; \mathrm{V}=$ Vespridromites spp.; $\mathrm{D}=$ Dioratiopus sp.; Ant = Antarctiprosopon chaneyi. Base maps from SCOTESE (2001) with data from SCHWEITZER et al. (2010). 
Glaessner, M.F. (1969): Decapoda. - In: Moore, R.C. (Ed.): Treatise on Invertebrate Paleontology, R (4) (2): R400-R533, R626-R628; Boulder \& Lawrence (Geological Society of America \& University of Kansas Press).

Glaessner, M.F. (1980): New Cretaceous and Tertiary crabs (Crustacea: Brachyura) from Australia and New Zealand. - Transactions of the Royal Society of South Australia, 104: 171-192.

Guinot, D. (1977): Propositions pour une nouvelle classification des Crustacés Décapodes Brachyoures. - Comptes Rendus Hebdomadaires des Séances de l'Académie des Sciences, (D), 285: 1049-1052.

Guinot, D. (1991): Établissement de la famille des Poupiniidae pour Poupina hirsuta gen. nov., sp. nov. de Polynésie (Crustacea Decapoda Brachyura Homoloidea). Bulletin du Muséum National d'Histoire Naturelle, (4), 12: $577-605$.

Guinot, D. (1995): Crustacea Decapoda Brachyura: Révision des Homolodromiidae Alcock, 1900. - In: CrosNIER, A. (Ed.): Résultats des campagnes MUSORSTOM, Volume 13. - Mémoires du Muséum national d'Histoire naturelle, 163: 155-282.

Hammer, Ø., Harper, D.A.T. \& Ryan, P.D. (2001): PAST: paleontology statistics software package for education and data analysis. - Palaeontologia Electronica, 4 (1): 9 pp.

International Commission on Zoological Nomenclature (1999): International Code of Zoological Nomenclature. - 306 pp.; London (International Trust for Zoological Nomenclature).

Karasawa, H., Schweitzer, C.E. \& Feldmann, R.M. (2008): Revision of the Portunoidea RAfINESQUe, 1815 (Decapoda: Brachyura) with emphasis on the fossil genera and families. - Journal of Crustacean Biology, 28: 82-127.

Linnaeus, C. v. (1758): Systema Naturae per Regna tria Naturae, secundum classes, ordines, genera, species, cum characteribus, differentiis, synonymis, locis (10th ed.), 1: 1-824; Laurentii Salvii, Holmiae [= Stockholm]).

Meyer, H. v. (1857): Briefliche Mitheilungen. - Neues Jahrbuch für Mineralogie, Geologie, Geognosie und Petrefaktenkunde, 1857: 556.

Milne-Edwards, A. (1880): Études préliminaires sur les Crustacés, 1ère partie. Reports on the Results of Dredging under the Supervision of Alexander Agassiz, in the Gulf of Mexico, and in the Caribbean Sea, 1877, '78, '79, by the U.S. Coast Guard Survey Steamer 'Blake', Lieutenant-Commander C.D. Sigsbee, U. S. N., and Commander J.R. Bartlett, U. S. N., commanding. VIII. - Bulletin of the Museum of Comparative Zoology, Harvard, 8 (1): 1-68.

NoetLing, F. (1881): Ueber einige Brachyuren aus dem Senon von Maestricht und dem Tertiär Norddeutschlands. - Zeitschrift der Deutschen Geologischen Gesellschaft, 33: $357-371$.

Ortmann, A.E. (1892): Die Abtheilungen Hippidea, Dromiidea und Oxystomata: die Decapoden-Krebse des Strassburger Museums, mit besonderer Berücksichtigung der von Herrn Dr. DöDERlein bei Japan und bei den LiuKiu-Inseln gesammelten und z. Z. im Strassburger Museum aufbewahrten Formen. V. Theil. - Zoologische Jahrbücher, 6: 532-588.
Patrulius, D. (1959): Contributions à la systématique des Décapodes néojurassiques. - Revue de Géologie et Géographie, 3 (2): 249-257.

Quenstedt, F.A. (1856-1857): Der Jura. - 842 pp.; Tübingen (Laupp).

RafinesQue, C.S. (1815): Analyse de la nature, ou tableau de l'univers et des corps organisée. - 224 pp.; Palermo (J. Barravecchia).

RichARDS, B.C. (1975): Longusorbis cuniculosus: a new genus and species of Upper Cretaceous crab with comments on the Spray Formation at Shelter Point, Vancouver Island, British Columbia. - Canadian Journal of Earth Sciences, 12: 1850-1863.

Schweitzer, C.E. \& Feldmann, R.M. (2005): Decapods, the Cretaceous-Palaeogene Boundary, and Recovery. - In: Koenemann, S. \& Jenner, R. A. (Eds.): Crustacea and Arthropod Relationships. - Crustacean Issues, 16: 1753; Boca Raton (Taylor \& Francis).

Schweitzer, C.E. \& Feldmann, R.M. (2008 [imprint 2007]): A new classification for some Jurassic Brachyura (Crustacea: Decapoda: Brachyura: Homolodromioidea): families Goniodromitidae BEURLEN, 1932 and Tanidromitidae new family. - Senckenbergiana Lethaea, 87: 119-156.

Schweitzer, C.E. \& Feldmann, R.M. (2009a): Revision of the Prosopinae sensu Glaessner, 1969 (Crustacea: Decapoda: Brachyura) including 4 new families and 4 new genera. - Annalen des Naturhistorischen Museums in Wien, (A), 110: 55-121.

Schweitzer, C.E. \& Feldmann, R.M. (2009b): New species of Longodromitidae Schweitzer \& Feldmann, 2009, from the Ernstbrunn Formation, Late Jurassic (Tithonian), Austria. - Annalen des Naturhistorischen Museums in Wien, (A) 111: 207-224.

Schweitzer, C.E. \& Feldmann, R.M. (2010a): The genus Coelopus Étallon, 1861 (Brachyura: Glaessneropsoidea: Longodromitidae) with new species. - Neues Jahrbuch für Geologie und Paläontologie, Abhandlungen, 258: $51-60$.

Schweitzer, C.E. \& Feldmann, R.M. (2010b): The Sphaerodromiidae (Brachyura: Dromiacea: Dromioidea) in the fossil record. - Journal of Crustacean Biology, 30: 417429.

Schweitzer, C.E., Feldmann, R.M., Garassino, A., KaRASAWA, H. \& Schweigert, G. (2010): Systematic List of Fossil Decapod Crustacean Species. - Crustaceana Monographs, 10: 222 pp.

Schweitzer, C.E., Feldmann R.M. \& LazĂr, I. (2007): Decapods from Jurassic (Oxfordian) sponge megafacies of Dobrogea, Romania and reconsideration of Nodoprosopon Beurlen, 1928. - Neues Jahrbuch für Geologie und Paläontologie, Abhandlungen, 244: 99-113.

Schweitzer, C.E., Nyborg, T.G., Feldmann, R.M. \& Ross, R.L.M. (2004): Homolidae De HaAn, 1839 and Homolodromiidae Alcock, 1900 (Crustacea: Decapoda: Brachyura) from the Pacific Northwest of North America and a reassessment of their fossil records. - Journal of Paleontology, 78: 133-149.

Scotese, C.R. (2001): Atlas of Earth History, volume 1. Paleogeography, PALEOMAP Project. - 52 pp.; Arlington. 
Stebbing, T.RR. (1920): South African Crustacea (Part X of S. A. Crustacea, for the Marine Investigations in South Africa). - Annals of the South African Museum, 6: 231593.

Stimpson, W. (1858): Prodromus descriptionis animalium evertebratorum, quae in Expeditione ad Oceanum Pacificum Septentrionalem, a Republica Federata missa, Cadwaladaro Ringgold et Johanne Rodgers ducibus, observavit et descripsit. Pars VII. Crustacea Anomura. - Proceedings of the Academy of Natural Sciences of Philadelphia, 10: 225-252.

VAN Binkhorst, J.T. (1857): Neue Krebse aus der Maestrichter Tuffkreide. - Verhandlungen des Naturhistorischen Vereins der Preußischen Rheinlande und Westfalens, 14: $107-110$.

VAn Straelen, V. (1936): Crustacés Décapodes nouveaux ou peu connus de l'époque Crétacique. - Bulletin du Musée Royal d'Histoire Naturelle de Belgique, 12 (45): $1-49$.

Woods, J.T. (1953): Brachyura from the Cretaceous of central Queensland. - Memoirs of the Queensland Museum, 13: 50-57.
Wright, C.W. \& Collins, J.S.H. (1972): British Cretaceous crabs. - Palaeontographical Society Monographs, 126 (533): 1-113.

Wright, C.W. \& Collins, J.S.H. (1975): Glaessnerella (Crustacea Decapoda, Cymonomidae), a replacement name for Glaessneria Wright \& Collins, 1972 non TAKedA \& MiyaKe, 1969. - Palaeontology, 18 (2): 441.

Manuscript received: May 18th, 2010.

Revised version accepted by the Stuttgart editor: May 28th, 2010.

\section{Addresses of the authors:}

Carrie E. Schweitzer, Department of Geology, Kent State University at Stark, 6000 Frank Ave. NW, North Canton, Ohio 44720, USA;

e-mail: cschweit@kent.edu;

Rodney M. Feldmann, Department of Geology, Kent State University, Kent, Ohio 44242, USA;

e-mail: rfeldman@kent.edu 